\section{UNIVERSITY \\ of DEBRECEN \\ FACULTY OF \\ HEALTH}

NYÍREGYHÁZA

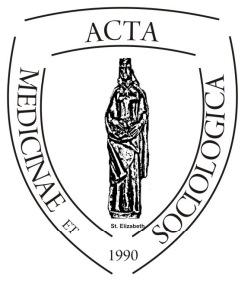

ACTA

MedSoc

VOLUME 5.

2014

\title{
Az idők szava \\ Az angol továbbképzési és szakképzési \\ rendszer kihívásai a XXI. század elején
}

\author{
Zolnai Erika
}

\author{
Debreceni Egyetem, Egészségügyi Kar
}

\begin{abstract}
The Time Password Challenges of the English Further Education and Vocational Education Training System at the Beginning of the 21st Century.

The restructuring of the labour market, the altered needs of the industrial and service sector, and the technological development expect fundamentally different training supplies from the educational system. Substantive, methodological and structural changes are also necessary to increase both the quantitative and qualitative requirements. The expansion of higher education in the 21 st century has destructed the demand from vocational education, while the employers' side is constantly lack of advanced, highskilled employees. On the other hand however, the large number of low-skilled, unqualified underdogs on labour market also accurs as an extremely severe problem. How can a country with a strong economic background as the United Kingdom deal with its vocational education in a situation, where educational traditions, that are resistant to changes - similarly to the Hungarian educational system, have led to unhealthy educational selection? The reforms of the 1980s are helped to restore the economical system, but at the same time serious social and territorial inequalities were left behind.

In this summary, we slightly emphasize the historical aspects of education, but we try to outline the srtucture of vocational education and its relationships with public and higher education, which provides an interpretative frame for this current issues and reform processes. What is actually happening in the last few years? The compulsory education attendance is increased above 18 years, the infrastructure of secondary education has been developed, the vocational educational system is reviewed, the
\end{abstract}


professional training of people under 25 is highly supported, and last but not least tere are several new experiments in the field of financial and collaborational systems. Heroic efforts are put in action in order to renew the apprenticeship system, which tries to raise qualification, work experience and employment, too. The most common obstacle for career starters is lack of work experiance. How it all works, what are its impeding factors and the challanges we have to face?

The vivid discussions within the educational policy, the contradictions between ensuring qualitiy and equity, as well as the activity of professional audience could be highly instructive for us. If one can learn from the experiences of others, same major mistakes, errors or any waste of existing values are probably avoided.

Key words: Education System UK, Vocational Education; Further Education, Apprenticeship, Educational Reform

Absztrakt. A munkaerő-piac átrendeződése, az ipari ágazat és a szolgáltatási szektor megváltozott szükségletei, valamint a technikai fejlődés alapvetően más képzési kínálatot vár az oktatási rendszertől, mint ami az utóbbi évtizedekre jellemző volt. Tartalmi, módszertani és strukturális változások egyaránt szükségesek a megnövekedett mennyiségi és minőségi elvárásoknak való megfeleléshez. Az ezredforduló felsőoktatási expanziója számos fejlett országban elvonta a keresletet a szakképzéstől, miközben a munkáltatói oldal folyamatosan hiányolja a korszerü, magas képzettségü munkavállalókat. A munkavállalói oldalon ugyanakkor feszítő problémaként jelentkezik a nagy számú, munkaerőpiacon esélytelen, alacsonyan kvalifikált, képzetlen fiatal. Mit kezd a szakképzésével ebben a helyzetben egy olyan erős gazdasági háttérrel rendelkező ország, mint az Egyesült Királyság, ahol a változásokkal szemben ellenálló oktatási hagyományok, hazánkhoz hasonló egészségtelen iskolai szelekciót eredményeztek? A 80-as évek reformjai a gazdaságot ugyan rendbe tették, de súlyos társadalmi és területi egyenlőtlenségeket hagytak maguk után.

Összefoglalónkban az oktatástörténeti vonatkozásokra kevéssé tudunk kitérni, de igyekszünk felvázolni a szakképzés struktúráját, a közoktatáshoz és a felsőoktatáshoz való viszonyát, ami egyfajta értelmezési keretét adja a jelenlegi problémáknak, és a reformfolyamatoknak. Mi is történik az utóbbi években? A tankötelezettséget 18+ éves korra emelik, javítják a középfokú képzések infrastruktúráját, felülvizsgálják a szakképzési rendszert, támogatják a 25 év alattiak szakmai képzését, új finanszírozási és együttmüködési rendszerekkel kísérleteznek. Heroikus erőfeszítéseket tesznek a gyakornoki rendszer megújítására, ami a képzettség mellett igyekszik a munkatapasztalat-szerzést és a foglalkoztatottságot is növelni. A pályakezdők elhelyezkedésének gyakori akadálya, hogy nincs munkatapasztalata. Hogyan müködik mindez, mik a gátló tényezők, milyen kihívásokkal kell szembenézni?

Az élénk szakmapolitikai vita, a minőség és az esélyegyenlőség biztosításának ellentmondásai a szakmai közvélemény aktivitása igen tanulságos lehet számunkra. Mások tapasztalatából tanulva, talán elkerülhető ugyanazoknak a tévedéseknek, hibáknak az elkövetése, esetleg meglévő értékeink elherdálása.

Kulcs szavak: oktatási rendszer, szakképzés, továbbképzés, gyakornoki rendszer, oktatási reform

DOI: $10.19055 / \mathrm{ams} .2014 .5 / 14-15 / 8$ 


\section{Bevezetés}

Az oktatási rendszeren belül a szakképzés helyzete kitüntetett jelentőséggel bír a társadalmi környezethez való alkalmazkodás, nem utolsó sorban a fejlesztés vonatkozásában. Indikátorként jelzi a közoktatásban gyökerező tendenciákat, problémákat. A munkaerőpiachoz való kapcsolódása miatt a gazdasági folyamatokkal is érzékeny kölcsönkapcsolat jellemzi. A szakképzés tehát magán hordozza az egész rendszer bajait, miközben saját teljesítményproblémái miatt a munkaerő és a nemzetgazdaság versenyképességének egyik közvetlen felelősévé is válik.

Az oktatás egészében fejlesztések és a mérési rendszerek összehangolásának igénye felértékeli a nemzetközi együttmüködés fontosságát, a tapasztalatok megosztását. A nemzeti oktatási rendszerek tanulmányozása felhívhatja a figyelmet a jelenségek, problémák mögött rejlő szerkezeti és funkcionális összefüggésekre. A nem eléggé körültekintő tervezés olyan pozitív visszacsatolásokat indíthat el, melyek váratlan, expanzív módon felerősíthetnek negatív tendenciákat (pl. szelekciós mechanizmusokat). A szakképzés szorosan beágyazódik a közoktatás és a felsőoktatás rendszerébe, vagyis a változtatásokat összehangoltan mindhárom szintet figyelembe véve kell megtervezni.

Coffey és Rhodes 2002-es összehasonlító elemzésében (Coffey \& Rhodes 2002) saját és a CEDEFOP jelentések vizsgálati eredményei alapján három központi kérdés köré rendezi a szakképzés helyzetének értelmezési keretét. (1) Milyen kulcskérdések mozgatják a változásokat a szakképzési rendszerben? (2) Milyen válaszokat ad a VET (Vocational Education Training) struktúrája ezekre a változásokra? (3) Mit jelentenek ezek a válaszok a VET finanszírozásában?

Tanulmányukban a meghatározó európai modelleket ismertetik, megvizsgálják, hogyan reagál a szakképzési rendszer a munkaszervezés változásaira, illetve a foglalkoztatott személyek speciális körülményeire. Felvetik a kérdést, hogy a munkáltatók és az egyének szükségleteinek változásai hogyan jelennek meg a jelenlegi modellekben, a munkának, illetve a munkavállalók szakmai képzettségének, kompetenciáinak milyen új definícióira tesznek javaslatokat. Fontos vizsgálati szempont a finanszírozás, milyen az együttmüködés az állami képző intézmények, az üzleti alapú vállalkozások, az államilag finanszírozott szereplök, és a vállalkozások, cégcsoportok között. Különösen fontos, hogy milyen egyeztetések zajlanak a finanszírozásról a szakképzés hasznát élvező munkáltatók, személyek és az állam között (Lauterbach U. and Sellin B. 2000). A 2003tól kétévente megjelenő NESS Jelentés (National Employer Skills Survey for England Report) hasonló rendszerben vizsgálja a szakképzés különböző indikátorainak alakulását az Egyesült Királyság terültén. A jelentést az UKCESS elne- 
vezésủ bizottság (UK Commission for Employment and Skills rövidítve UKCESS) készíti el és hozza nyilvánosságra ${ }^{1}$. Adataik fontos kiinduló pontjai a helyzetelemzésnek és stratégiai tervezésnek.

\section{A közoktatási háttér}

Az angol közoktatás rendszere rendkívül színes, és több szempontból is tagolt. Számtalan csoportosítás született nemcsak a nemzetközi összehasonlítási igény, hanem a résztvevők eligazodása érdekében is. Elnevezésük tükrözi a hagyományokat (pl. Sixth-form School / nincs magyar megfelelője, Grammar School / Gimnázium) miközben utal az intézménytípus egy-egy jellegzetességére (fenntartó, oktatási forma, alapítás), miközben a hivatalosan használt elnevezések mellett számos nem hivatalos köznyelvi forma is megjelenik. Találkozunk ugyanakkor a nemzetközi nomenklatúrának megfelelő kategóriákkal is (pl. primary; lower secondary, upper secondary education / általános, alsó középiskolai, felső középiskolai képzés), ezek azonban nem iskolatípust, inkább oktatási szintet jelentenek, többféle iskolatípus tartozik hozzájuk.

A részletes ismertetéstől el kell tekintünk, a rendszer megértéséhez a melléklet első két táblázata nyújt támpontot. A tagoltság egyben különbségeket, egyfajta hierarchiát is jelent a különböző programot nyújtó iskolák között. A szülők szabad iskolaválasztási joga és az iskolák felvételi rendszere (bár részben korlátozott) a világ egyik legalacsonyabb életkorban induló iskolai szelekcióját eredményezi. A legjobb képességü gyerekek sorsáról már 11 évesen eldöntik, hogy az akadémiai képzés, vagy a szakmai képzések irányába induljanak-e tovább. Ez az egyik legrégebbi, és legnehezebben kezelhető dilemmája az angol oktatáspolitikának. A reformoknak egyszerre kellene az oktatás hagyományokra épülö elitképzés minőségi elvárásait megtartani, ami a társadalmi különbségeket kiélezi, miközben az esélyegyenlőség, társadalmi integráció feladataira is megfelelő válaszokat kellene adnia. Érthető módon a jobb és bal oldali kormányok eltérő módon súlyozták a problémát, és a nagy társadalmi nyomás miatt eddig egyik oktatási reformnak sem sikerült érdemlegesen befolyásolni ezt a helyzetet.

A finanszírozás és szabályozás tekintetében az Egyesült Királyságban a központi kormányzat teljes felelősséget vállal az oktatási rendszerért, ugyanakkor az oktatás irányításának rendszere decentralizált, a fenntartói feladatokat az önkormányzatok, az önkéntes szolgáltatók, az egyházak, az oktatási intézmények irá-

\footnotetext{
${ }^{1}$ UK Employer Skills Survey 2011: First Findings. http://www.ukces.org.uk/assets/ukces/docs/publications/uk-ess-first-findings-2011amended-22-dec.pdf
} 
nyító testületei, és a tanári szakma együttesen végzik. Az angol iskolások mintegy 93 százaléka állami finanszírozású, bár különböző fenntartói kezelésében lévő iskolában tanul (önkormányzat, egyház, civilszervezet). Ezekben az oktatás ingyenes, csupán az állami bentlakásos iskolák számítanak fel meghatározott térítési díjat. A fennmaradó 7 százalék választja a magas tandíjjal müködő, bentlakásos magániskolákat.

A felügyeletet és a fenntartói feladatokat tehát a helyi önkormányzatok testületei végzik, az állam részéről ${ }^{2}$ az Ofsted (Office for Standards in Education Oktatási Hivatal) ellenőrzi a feltételeket és a minőséget. Az állami iskolák nagyfokú önállósággal rendelkeznek, önállóan gazdálkodnak, felelősek a saját költségvetésükért és a személyzettel kapcsolatos döntésekért. Saját irányító testületeik látják el az általános irányítási feladatokat, ezekben minden érdekelt fél képviselteti magát benne (iskola vezetése, tanárok, szülők), a stratégiai vezetést megosztja az iskolaigazgatóval, és utóbbi hozza a napi döntéseket. A széles körü autonómia és decentralizáció ellensúlyozásaként az angol oktatási rendszert nagyfokú elszámoltathatóság jellemzi, beleértve az iskolai teljesítmények adatainak nyilvánosságát, és az iskola rangsorokat is.

A hatályos oktatási törvény a tankötelezettséget több lépésben 2015-ig 18+ $\mathrm{ra}^{3}$ emeli, ami a közép és felsőfokú képzések, ezen belül a szakképzés jelentőségét és szerepét növeli. Minden iskolára érvényes a Nemzeti Alaptanterv (National Curriculum), melyet az „Oktatási és szakképzési törvény” (2008 Education and Skills Act) ${ }^{4}$ szabályoz, és ez adja a keret a helyi tanterveknek. A három központi tantárgyat (angol, matematika, és természettudomány) 5-16 éves korig kötelező tanulni, míg az alaptárgyaknak nevezett tantárgyakat egy vagy több évfolyamon (Kay Stage / KS) tanulják (müvészetek és dizájn, állampolgári ismeretek, dizájn és technológia, földrajz, történelem, IKT, modern idegen nyelvek, zene, testnevelés). Ezen kívül minden évfolyamon van vallási nevelés, és a KS2től szexuális nevelés, karriernevelés, végül munkával kapcsolatos oktatás a 3. és 4. KS-től (hetedik osztálytól). A tantervnek fontos része a munkatapasztalatszerzés, ami szoros kapcsolatot épít ki a helyi cégekkel, vállalkozókkal, mivel ők biztosítják a gyakorlati helyeket. A készségek, képességek megismerése és fejlesztése mellett ez jó lehetőség a tanulók számára a továbbtanulással kapcsolatos döntésekhez szükséges pályaorientációs információk megszerzésére.

Az angol oktatási rendszerben többféle iskolatípus és hagyományos tagozódás él egymás mellett a fenntartás és finanszírozás különbségein túlmenően is. A ha-

\footnotetext{
${ }^{2}$ Oktatási Minisztérium (Department for Education - Dfe), és az Üzleti, Fejlesztési és Szakmai Minisztérium (Department for Business, Innovation and Skills - BIS) felügyeli.

${ }^{3} \mathrm{Nem}$ az életkor betöltéséhez kötött, hanem a megkezdett iskolai év befejezéséhez, ami többnyire 19 éves kor.

${ }^{4} \mathrm{http}$ ://www.educationengland.org.uk/documents/pdfs/2008-education-and-skills-act.pdf
} 
gyományok egymás mellett élése a rendkívül tagolt vizsgarendszerben is tükröződik. Számos vizsgarendszer létezik a központi állami vizsgák mellett. Ezek részletes ismertetésétől ugyan el kell tekintenünk, azonban utalnunk kell rá, hogy a szakképzés hagyományai és jellegzetességei között a minősítési rendszernek és az ehhez kapcsolódó vizsgarendszernek meghatározó szerepe van, éppen ezért a szakképzés kapcsán később visszatérünk rá.

A tanárokat a nemzeti szinten elfogadott életpályamodell (School Teachers' Pay and Conditions Document) szerint foglalkoztatják, anyagi megbecsültségük az európai élmezőnyéhez tartozik. Kezdő fizetésük magasabb az átlagos diplomás kezdő fizetésnél (21.804-27.270 GBP), a vezető tanárok ennek kétszeresét is megkereshetik (57.520-64.677 GBP). Az iskolaigazgatók juttatása ennél lényegesen magasabb - intézménytől függően 43 ezertől akár 113 ezer fontig terjed. A fizetések erősen függnek a tanárok személyes teljesítménytől, az éves értékelések progresszív előrejutást biztosítanak a fizetési kategóriákban ${ }^{5}$. Látni fogjuk, hogy az utóbbi évtizedekben és jelenleg is az Egyesült Királyság azon európai országok egyike, amelyek a legtöbbet költik az oktatási rendszerükre, ami nagyarázza, hogy ennek megfelelő teljesítményt és hatékonyságot várnak el a pedagógusoktól.

\section{A szakképzés betagozódása az iskolarendszerbe, tanulási utak}

A szakképzés törvényi hátterét az 2009-ben megszületett „Szakképzési törvény” (Apprenticeships, Skills, Children and Learning Act 2009) ${ }^{6}$ jelenti. Ahogyan a 2es számú táblázat mutatja a közoktatás és a szakképzés szorosan összekapcsolódik, rendszere csak összefüggésükben értelmezhető?

\footnotetext{
${ }^{5} \mathrm{http}: / /$ www.education.gov.uk/get-into-teaching/salary

${ }^{6} \mathrm{http}: / /$ www.legislation.gov.uk/ukpga/2009/22/notes/contents

${ }^{7} \mathrm{Az}$ áttekinthetőség érdekében számos intézménytípust nem szerepeltetnek a legtöbb rendszerismertetésben. A mellékletben bemutatott táblázatban igyekeztünk összefoglalni a különböző időszakokban kialakult iskolatípusokat. A különböző elnevezések mögött többnyire eltérö fenntartói, tulajdonosi struktúra, esetleg finanszírozás fedezhető fel. A rendszer időbeni fejlődése hatására a tradicionális iskolatípusok és a különböző oktatási törvényekhez kötődő újabb alapítású formák párhuzamosan müködnek.
} 


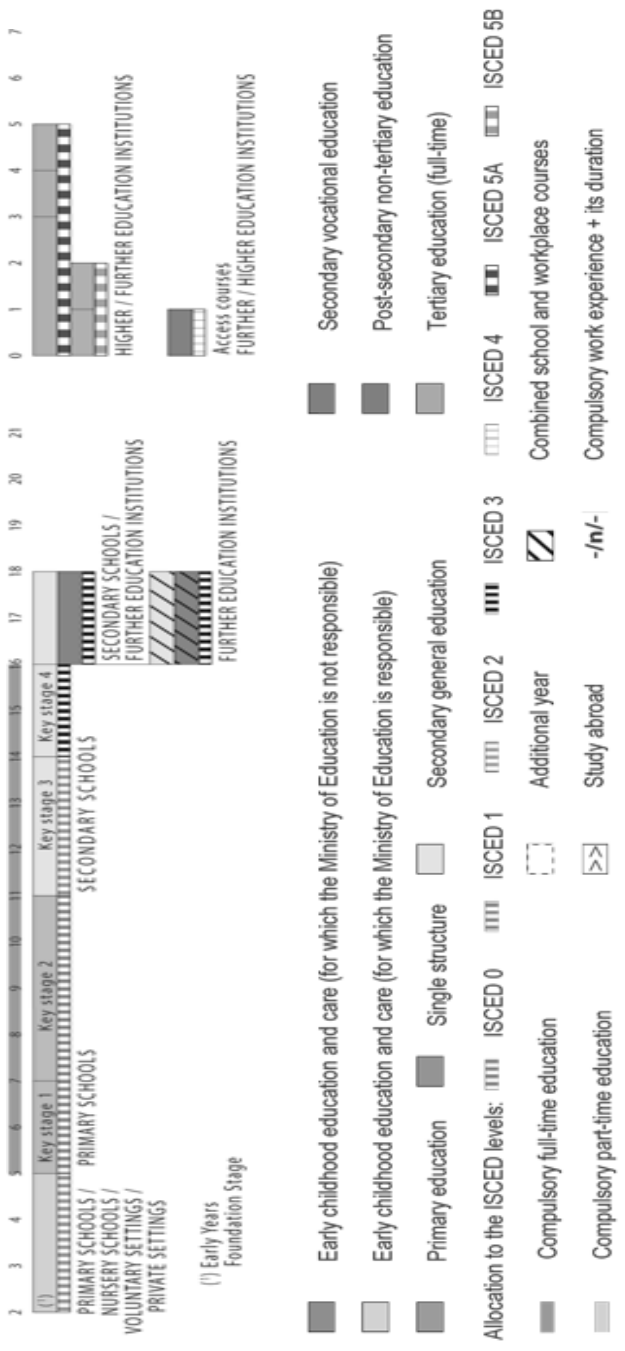

1. táblázat. Az angol oktatás struktúrája és a továbbtanulás.

Forrás: Eurydice https://webgate.ec.europa.eu/fpfis/mwikis/eurydice/index.php/UnitedKingdom-England:Overview 
Az alsó középfok szintjén pályaorientációs céllal munkatapasztalatokhoz jutnak a diákok, s mikor elérik 16 éves kort ${ }^{8}$ és megszerezték a GCSE (general certified secondary education) minősítést, akkor 2 tanulási útvonal lehetséges. Elméleti (academies), vagy szakmai (vocational) végzettséget (képesítést) szerezhetnek, melynek esélyei a különböző középiskola típusokban nem egyformák, ide pedig 11 évesen felvételiztek. Korábban a munkavállalásra is lehetőség volt, bár az alacsony, inkább hiányzó képesítések miatt szinte esélytelenül. Vannak tehát akik elindulhatnak az elméleti továbbképzés (further academic qualification) irányába vagy a szakmai karrierutat választják, így a kétéves szakképzés keretében képesítéseket szereznek különféle iskola formákban az iskolarendszeren belül (Sixth Form, ill. Sixth Form College vagy Further Education Institute).

Az említett szakképző iskolák 18 évesnél idősebb felnőttek számára is hirdetnek tanfolyamokat, ugyanakkor felnőttképzést indítanak az iskolarendszeren kívüli intézmények is. Az oktatásnak ezt az ágát nevezik továbbtanulásnak, vagy szakképzésnek (Futher Education, Vocational Education). Az eredetileg a felsöszintü (tertiary) szakképző intézmények (Polytechnics, Müszaki Főiskola - Angliában eredetileg 30 létezett), az 1992-es „Továbbképzési és felsőoktatási törvényben" önálló egyetemi rangot kaptak".

A Müszaki Főiskolák átvezetnek bennünket a szakképzés felső fokú szintjére és a felsőoktatáshoz való kapcsolódási pontokhoz, melyben megtaláljuk a gyógyító-segitő, továbbá az adminisztráció és a menedzsment területen dolgozó szakemberek képzését is, melyek a felsőoktatáson belül más szabályozás alá tartoznak, mint a szakképzés. Ezek már felsőfokú (Level 4 Qualifications) minősítéseknek megfelelő diplomákat adnak az említett szakmai területeken, hasonlóan a hagyományosnak tekinthető elméleti egyetemi képzésekhez és az ún. szabályozott képzésekhez (oktatás, jog, orvostudomány, pszichológia, üzleti világ). melyek akadémiai végzettségek, diplomák és nem a szakmai végzettségek körébe tartoznak. Az utóbbi évek képzési reform folyamata során meghatározták a különböző képesítési rendszerek megfelelőségét (pl. akadémiai és szakmai), erről később szólunk.

\footnotetext{
${ }^{8}$ Korábban oktatási kötelezettség végét jelentette, napjainkban ennek elindult a fokozatos emelése 18/19 évre.

${ }^{9}$ A felsőoktatási rendszer minősítéseinek összefüggései: http://www.ecctis.co.uk/europass/documents/ds_chart.pdf
} 


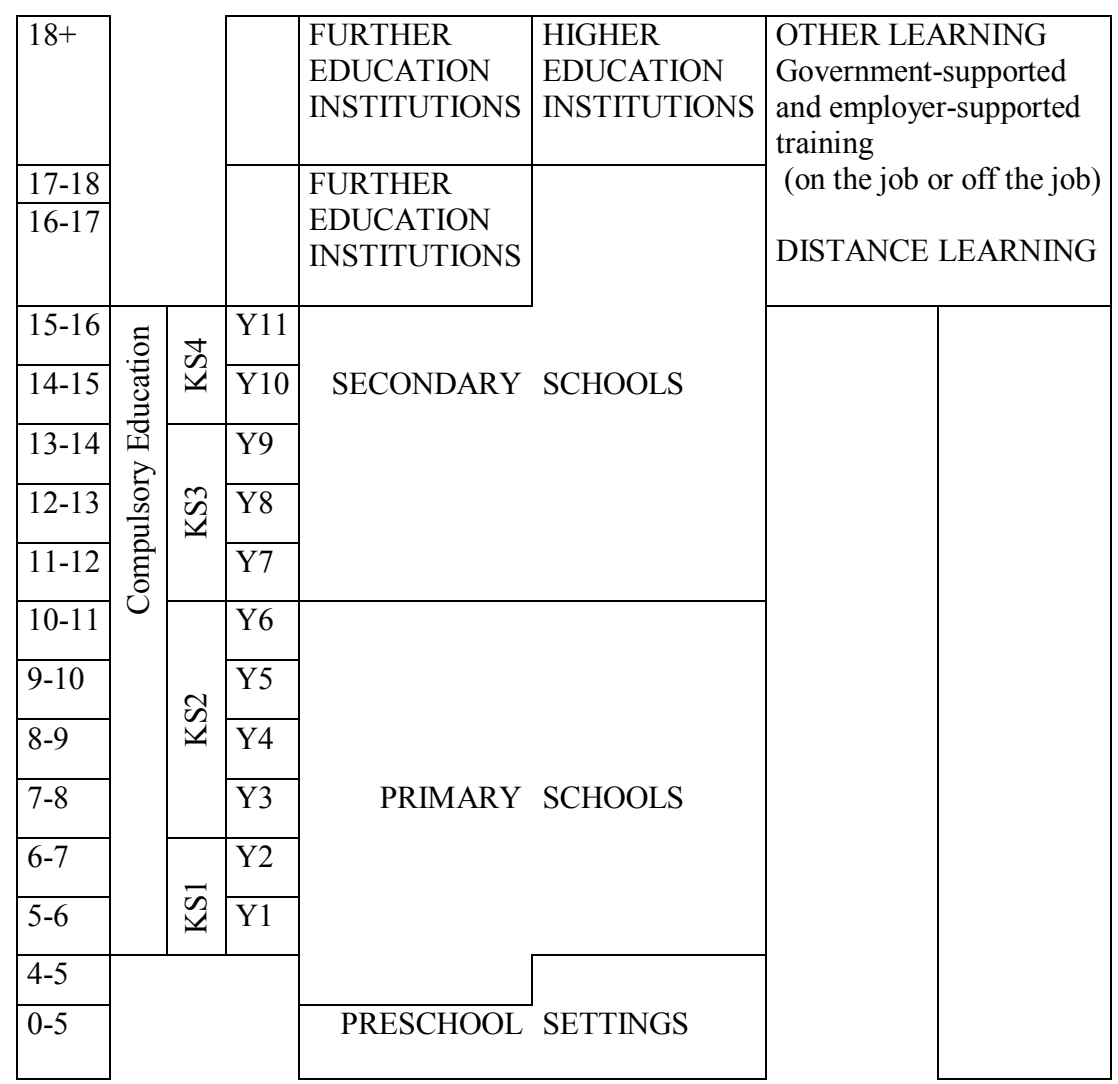

2. táblázat. Szakképzés helye az oktatási rendszerben forrás: $\mathrm{UNESCO}^{10}$

\section{Az angol szakképzési rendszer iskolarendszeren belüli, és iskolarendszeren kívüli elemei}

A továbbképzési kurzusok a „college” szektorban (főiskolai) állnak rendelkezésre, melynek intézményei vagy állami, vagy független fenntartásúak lehetnek, bár az utóbbi csupán az 5\%-át teszi ki az összesnek. Az iskolarendszeren kívüli szervezetek, szakképzési központok sokféle funkcióval rendelkeznek a tanfo-

\footnotetext{
${ }^{10} \mathrm{http} / / /$ www.ibe.unesco.org/Countries/WDE/2006/WESTERN_EUROPE/United_Kingd om/United_Kingdom.htm
} 
lyamok szervezésén túl is, például különböző szolgáltatásokat nyújtanak, melyekkel a programok elérhetőségét kívánják növelni (pl. tanácsadói szolgáltatások, felvételi előkészitő tanfolyamok).

A továbbképzési rendszer 2-es számú táblázat által szemléltetett módon átfedi a középfokú oktatást és a felsőoktatást is. Egyes programok már 11-16, mások 16-19 éves kor között nyújtanak lehetőségek szakképzettség megszerzésére, utóbbi életkorban a felsőoktatáshoz kapcsolódva is léteznek programok. Az FE continuuing education néven is ismert, régebbi irodalmak post compusory-ként is használták, amíg a kötelező oktatás 16 éves korig tartott. Ennek keretében beszélhetünk teljes vagy részidős képzésekről (full-time or part-time education) is, utóbbiak gyakran munka melletti képzések, akár fiatalok, akár felnőttek számára. Maguk a képzőintézmények lehetnek iskolarendszeren belüli és azon kívüli úgy nevezett képzési szolgáltató intézmények.

1994-től vezették be az államilag finanszírozott ún. Modern Gyakornoki Rendszert (Modern Apprenticeship) a szakképzettség növelése céljából, melynek lényege „quality training on a work-based (educational) route", azaz munkalapú képzési filozófia. Az alacsonyabb képzési szinteken a cél a munkatapasztalat biztosítása, minél több munkahely, szakma megismertetése, majd a különböző fokú szakmai kompetenciák elsajátítása. Az eltérő felkészültségü diákok előképzettségükhöz igazodva elégítik ki, segítenek pótolni a hiányosságaikat, és kínálnak angol nyelvtanfolyamokat is. A program fö finanszírozója a Business And Technology Education Council (Üzleti és Müszaki Oktatásfinanszírozási Tanács). John Hayes Gyakornoki rendszerért felelős Miniszter (Joint Minister for Apprenticeship) felügyelete mellett a Nemzeti Gyakornoki Szolgálat (National Apprenticeship Service) hozta létre a Gyakornoki Program Tanácsot (Apprenticeship Program Board), ami koordinálja a két felelös minisztérium (Department for Business Innovation \& Skills és a Department for Education) bizottságait (BIS - Skills Strategy Board és DfE- Curriculum and Qualifications Board) és jelentést készít a felelős miniszternek (Minister for Apprenticeship) ${ }^{11}$. A gyakornoki rendszer megújítására számos kísérlet történt az utóbbi évtizedekben, a legfrissebb változásokról részletesebben a reformfolyamatok kapcsán számolunk be. A gyakornoki rendszer (1994-től Modern Gyakornoki Rendszer) tanulói létszámának és összetételének változásait 1950-2010-ig a 4-es számú melléklet grafikonján lehet követni.

\footnotetext{
${ }^{11}$ Business Plan 2012-13 of National Apprenticeship Service. http://www.apprenticeships.org.uk/About-Us/ /media/Documents/NAS-201213BusinessPlanforstakeholders-July2012.
} 
A szakmai képzéseket a finanszírozás forrása szerint 4 kategóriában kezelik:

1. Szakmai alapképzés (kezdő szakképzés / Initial Vocational Training IVT vagy FE continuuing education az amerikai angol terminológia szerint) 16-19 évesek képzése (kivéve a felsőoktatást) föiskolákon (Colleges) 55\%, munkahelyeken $37 \%$ és iskolákban $8 \%$ zajlik. Ez államilag finanszírozott, tandíjmentes képzés.

2. Szakmai továbbképzés (Vocational Education and Training) azokat szólítja meg, akik foglalkoztatásban vannak, tartalmazza a 16-19 éveseket az IVT-ben a munkahelyeken, képzési szolgáltatóknál, föiskolákon. A franchise -nak, vagy főiskolák/ munkahelyi alapú képzést végző trénerek számának növekedése jellemzi, a szakismeretek aktualizálását szolgálja.

3. Felnöttképzés (Adult Education) - az iskolarendszeren belüli intézmények is kínálnak tanfolyamokat felnőtteknek, részidőben, esetleg munkahelyeken, de a speciális felnőtt-képző intézmények programjai is elérhetőek. A támogatott felnőtt képzés legújabb stratégiája szerint a National Institute of Adult Continuing Education (NIACE) ${ }^{12}$ szervezett, irányított formában, nemzeti szinten kívánja megvalósítani a „több, különböző és jobb felnőtt képzést"13.

3. Képzések munkanélküliek számára. Képzések azok számára, akik 19 évesek elmúltak és munkanélküliek. Piacképes szakismeretek az elhelyezkedési esélyek javítása érdekében.

A képzéseket lebonyolító intézmények nagyon változatosak, és inkább szakmai szempontból specializáltak. Különböző szintü minősítő vizsgákra felkészítő képzéseket indítanak, és nem választhatók el a Modern Apprenticeship (Modern Gyakornoki) rendszertől, melynek megújítása jelenleg is zajló, sok vitát kiváltó folyamat. A képzéseknek három szintje van, (1) Intermediate (5GCSE); (2) Advance (2A); (3) Higher (NVQ Level 4 vagy Foundation Degree) ${ }^{14}$.

A Felnőtt (25 év felettiek) Gyakornoki rendszer (Adult App.), ugyanezt a szakmai tapasztalatszerzést és képesítés megszerzését nyújtja. 16-18 éves kor között a képzés költségét a kormány finanszírozza, 18-24 éves kor között az $50 \%$-a terheli a tanulót, a másik felét a kormány átvállalja, 25 éves kor felett a képzésért fizetni kell, melyhez diákhitelt lehet igénybe venni.

A gyakornoki rendszer egyszerre biztosít munkahelyi gyakorlatot, ahol a tanulót meghatározott minimálbér, szabadság illeti meg, és tanfolyamot, ahol a szakmai készségek képességek mellett angolt, matematikát, és természettudományos tantárgyakat is tanulnak. A szakmai szerepnek és munkakörnek megfe-

\footnotetext{
${ }^{12} \mathrm{http}: / /$ www.niace.org.uk/about-us/governance

${ }^{13} \mathrm{http} / / / \mathrm{www}$. niace.org.uk/sites/default/files/documents/policy/niace_strategic_plan_201 3-18.pdf

${ }^{14} \mathrm{http} / / /$ www.legislation.gov.uk/ukpga/2011/21/pdfs/ukpga_20110021_en.pdj
} 
lelő, előre meghatározott kreditek megszerzésére nyílik lehetőség és felkészítenek a minősítő vizsgára.

A képzéseket biztosító intézmények között találjuk a General Further Education és a Tertiary Colleges intézményeit, valamint a Sixth Form College-kat, és Specialist College-okat (ezek mezőgazdasági, kertészeti, dráma, és tánc specializációjú iskolák). Ezek már a felsőfokú szakképzésekhez tartoznak 18 éves kor felett, párhuzamosan az egyetemekkel és egyéb felsőoktatási intézményekkel. A felsőfokú szakképzés tehát külön intézményrendszerben valósul meg.

Az utóbbi időben számos új elemmel bővült az egyébként is színes rendszer, mely tartalmazza a továbbképző (szakképző) főiskolákat (Further Colleges), müszaki föiskolákat (Technical Institute), szakképző központokat (UTC - University Technical Colleges), müvészeti és müszaki föiskolákat (Art and Technical Collages), felsőfokú szakképző intézményeket (Tertier Colleges; alap, közép és felsőfokú képzési tagolásnak megfelelően). A 16 éves kor utáni középfokú oktatásban a Sixth Form College-ok is nyújtanak szakmai képzéseket. Ezek nálunk inkább a középiskolai szintnek felelnek meg, vagy a franciaországi, vagy a Romániában ismert Líceumnak. A skála másik végén azok a föiskolák vannak, melyek alap szintủ szakmai képzéseket nyújtanak, és kapcsolatban vannak a felsőoktatással és az Egyetemi szektorral (HE).

Röviden összegezve, a szakképzés rendszerében a finanszírozás a résztvevők életkori csoportjaihoz kötődik, ennek megfelelően vállal szerepet a kormány, illetve jelenik meg az önfinanszírozás és a diák hitel. A szakképzésben szerepet vállaló intézmények és programok szövevényes rendszerében a képzési célok, kimenetek alapján egyéni karrierutakat ajánlanak a jelentkezőiknek ${ }^{15}$. A legalacsonyabb képzési szinten (Traineeship) is tartozik a munkatapasztalat-szerzéshez angol és matematika oktatás, valamint a munkavállalói készségek fejlesztése. A képzési szintek növekedésével a szakmai kompetenciák egyre önállóbb munkavégzésre adnak felhatalmazást. A szükséges információk internetes alkalmazások segítségével böngészhetőek ${ }^{16}$, a döntésekben pedig tanácsadó szolgáltatások ${ }^{17}$ segítik a tanulókat. A képző intézmények egy része egyetemi felvételi vizsgára is felkészít és a szakmai vizsgák mellett az érettségi vizsgát is megszerzik a diákok. A tanulói utakat a megszerzett, illetve megcélzott vizsgák határozzák meg, a szakmák illetve a foglalkoztatás kritériumai a későbbiekben ismertetésre kerülő minősítési rendszer tartalmazza. Ez a kimeneti kritériumok mellett a képzések indítására és adminisztrációjára vonatkozó szabályozásokat is tartalmazza. Szolgáltatók széles köre

\footnotetext{
${ }^{15} \mathrm{http}: / /$ www.semta.org.uk/careers

${ }^{16} \mathrm{https}$ //apprenticeshipvacancymatchingservice.lsc.gov.uk/navms/forms/candidate/Appr enticeships.aspxó

${ }^{17} \mathrm{http}$ ://www.nacro.org.uk/what-we-do/education-services/
} 
érhető el az üzleti vállalkozásként müködő online adatbázisban ${ }^{18}$, ez azonban csupán egy nyilvántartás, nem hivatalos képzési jegyzék. Az Ofqual rendszerében az intézményt és a programot is akkreditáltatni kell.

\section{Képzési szolgáltatók}

A képzések megvalósításában piaci és non-profit szereplök is részt vesznek, mint képzési szolgáltatók, kínálatuk meglehetősen különböző, attól függően milyen célcsoportra specializálódtak.

Az AELP (Association of Employment and Learning Providers) ${ }^{19}$ a foglalkoztatási és képzési szolgáltatók legnagyobb bázissal rendelkező egyesülete Nagy-Britanniában, több, mint 600 tagja van, és non-profit és önkéntes szektor képző és foglalkoztatási szolgáltatóinak a szervezeteként müködik. A munkaalapú oktatásban érdekelt továbbképző intézmények (FE colleges) 50\%-át tömöríti, erőteljes lobbitevékenységet folytat, tagjai a képzések mintegy $70 \%$-át nyújtják országszerte.

Meg kell még említenünk a LANTRA szervezetét, aminek a bázisa az SSC (Sector Skill Councils), s mint ilyen a szakképzésben az ipari vállaltok képzési igényeit képviselik, a képzések és szakképzés, valamint munkaerő fejlesztését tekinti az üzleti sikerek alapjának.

A képzési programok ezeknél a szolgáltatóknál is lehetnek teljes, vagy részidősek, különböző célú tanfolyamokat ölelnek fel, melyek eltérő arányban tartalmazzák az alkalmazkodási készséget növelő (Skill for life), és speciális szakmai készségeket (professional skills). Kínálnak tanfolyamokat az élethosszig tartó tanulás keretében közösségfejlesztő céllal is (Community Learning), és a felnőttképzésben szakmai tanulás, továbbképzés céljából, a gyakornoki rendszertől függetlenül.

\section{University Technical Colleges}

Érdemes külön kiemelni a legújabb intézménytípust, mivel ez képviseli a legkorszerübb szemléletet a képzők és munkáltatók kapcsolatában, valamint a finanszírozás megvalósításában. Ezek speciális, újonnan alapított müszaki főiskolák (UTC $^{20}$, melyekből 2013-ig 17 kezdte meg a működését, és 2015-ig legalább 50 indítását tervezik. Leginkább a szektorok szoros együttmüködése különbözteti

\footnotetext{
${ }^{18} \mathrm{http}: / /$ www.trainingdirectoryuk.com

${ }^{19} \mathrm{http}: / /$ www.aelp.org.uk/about/

${ }^{20}$ University Technical College http://www.utcolleges.org/
} 
meg a többi iskolatípustól, hiszen indításának feltétele egy egyetem valamint ipari, üzleti cégek strukturális és funkcionális jelenléte az oktatásban, ami nem csupán adminisztratív, alapítói szerepet jelent, hanem aktív részvételt. Az iskolakötelezettség életkorának felemelésével a képző intézmények számát, formáit, és kapacitását is bővíteni kellett.

A képzési kínálatukra jellemző, hogy általában 1 vagy 2 éves egymásra épülő kurzusokat indítanak (esetenként szakmacsoportos formában), finanszírozásuk, müködésük azonban lényegesen eltér a régebbi típusoktól. 14 éves kortól 19 éves korig kínálnak szakmai képzéseket a diákoknak (egyes iskolák 11 éves kortól indulnak, de Sixth Form rendszerben is müködnek, azaz középiskola után is elkezdhetőek).

Lord Baker, korábbi Oktatási Államtitkár kezdeményezésével és támogatásával indult a fejlesztés, bár számuk még nem jelentős, figyelemre méltó a szektorok együttmüködésére és a szakképzés rangjának az emelésére tett kormányzati eröfeszítés. Különböző szakmákban kínálnak különböző szintü képzéseket (Apprenticeships Leves 2 - L4), egyetemi felvételi előkészítést és felvételi vizsgát, érettségit, továbbá felzárkóztatást is végeznek. Bentlakásos formában müködnek, meghatározott költségtérítést kell fizetni, szigorú napirend és egyenruha viselés kapcsolja a tradicionális angol oktatási rendszerhez. A szakmai kínálat a helyi lehetőségekhez és egyben igényekhez igazodik, azaz kapcsolódik a munkaerőpiachoz, meglévő foglalkoztatáshoz, hiszen a gyakorlati képzés ezek bevonásával történik.

A programmal kapcsolatban számos kritika is elhangzik a szakmai szövetségek oldaláról, mivel véleményük szerint így tovább darabolódik a képzési rendszer, és a meglévő intézményektől jelentős forrásokat vonnak el. Többségükbe 14 éves kortól jelentkezhetnek, amit sokan túl korainak tartanak a specializált szakmai elköteleződéshez.

\section{A képzés a minősítési rendszerek és vizsgaköz- pontok összefüggései}

Az angol képzési rendszerben a szakmák gyakorlásához szükséges képesítési elöírásokat a Nemzeti Képesítési Keretrendszer tartalmazza (National Qualifications Framework QCF $)^{21}$, melyhez a képzési krediteket a Minősítési és Kredit Rendszer (Qualifications and Credit Framework) rendeli hozzá, az Office of Qualifications and Examinations Regulation (Ofqual - Képzési és Vizsgaszabályozási Hivatal)

${ }^{21} \mathrm{http}: / /$ ofqual.gov.uk/qualifications-and-assessments/qualification-frameworks/ 
ellenőrzi és nyilvántartja a megszerzett képesítéseket, valamint a képző intézményeket akkreditálja az intézményeket és a képzéseket. Az angol rendszerben sokféle hagyomány él, számos vizsgarendszerrel és tradicionális vizsgaközponttal az állami mellett, így az országon belüli megfeleltetés is rendkívül fontos volt az Európai Képesítési Keretrendszerrel való összehangolás mellett.

Különböző szinteket lehet választani a kötelező középiskolai képzésben az alap készség tréningektől (basic skill training) a felsőfokú szakképzettségig; mint City and Guilds, Higher National Diploma or Foundation Degree. A GCSE és A szintü programok széles választéknak az a célja, hogy kiegészítse a közoktatásban kimaradt képességeket és ismereteket. Ez a legnépszerübb formája a felsőoktatásba való belépésnek (a legutóbbi vizsgálatok szerint ezek népszerűek ugyan, de nem eredményesek, kevesen kerülnek be ezen az úton a munkaerő piacra vagy a felsőoktatásba).

A felsőoktatási intézmények „Foundation and Access” elnevezésü egy éves elökészítő kurzusokat indítanak, melyek az egyetemi felvételi kritériumoknak megfelelőek (a természet tudomány, mérnöki, humán és orvostudomány területén). Számos különböző intézmény kapcsolódott ezekhez a felkészítő programokhoz, melyek belépők az egyetemi képzésbe.

A GNVQ (General National Vocational Qualification / Általános Nemzeti Szakmai Minősítés) alap, közép és felsőfokú programok alternatívát nyújtanak a diákoknak a tudományos A szintü képesítések mellett, amivel az egyetemre és a munkaerőpiacra is mehetnek. Népszerü területek: Art and Design; üzleti élet, egészségügyi és szociális terület, szabadidő és turizmus, kézmüipar, vendéglátás és ellátás, tudomány, mérnöki munka, informatika.

Jól példázza a végzettségek komplikált rendszerét a különböző végzettségek egyenértéküségének a bemutatása, melyet a „National Vocational Qualifications” és a „General National Vocational Qualifications” licenszei tartalmaznak. A 2016-ra meghirdetett hivatalos képzési lista, melyre 14-16 éves kortól jelentkezhetnek a tanulók 2015-ben, 20 oldalon kínál 60 - 480 kredit értékü (zömében 120 és 300 kredites) képzéseket, különböző képesítési szinteken (awards, certificate, diploma L1 és L2, melyek egyenértéküségéről a 3. ábra nyújt áttekintést). ${ }^{22}$ Ezeket a minősítéseket vizsgaközpontokban lehet megszerezni, melyekre a képző intézmények tanfolyamain lehet felkészülni. nagyon gyakoriak az alacsony képesítésre jogosító tanfolyamok, melyek az NVQ 1 és 2es szintjét nyújtják (6. táblázat).

A vizsgák minősítési kritériumait (Qualification standards) nyilvánosan közzé teszik. A kritériumok az utóbbi évek reformjai során sokat változtak ugyan, de alapvetően kompetencia alapú maradt a rendszer, az elméleti tudás kisebb

\footnotetext{
${ }^{22}$ https://www.gov.uk/government/uploads/system/uploads/attachment_data/file/266128/ 2016_KS4_Publication_list_final.pdf
} 
szerepet játszik. A vizsgán elsősorban azt határozzák meg, hogy a vizsgázónak milyen feladatok végrehajtásának képességével kell rendelkeznie az adott szinten. Feltételezik, hogy a feladatok végrehajtásához elméleti ismeretekkel is rendelkezni kell, de ezt külön nem kérik, és nem is rögzítik, mint a felkészítés feltételét. Ez alapvetően különbözik a magyar, de számos európai oktatási gyakorlattól, és curriculum rendszertöl. A vizsgán szimulált munkahelyi környezetben kell gyakorlati feladatokat végrehajtani. A szabályozást törvényben írják elő, a legújabb a 2011-es ${ }^{23}$. A szabályozás végrehajtásáért felelős intézmény az Office of Qualifications and Examinations Regulation Ofqual ${ }^{24}$, melynek honlapján minden szükséges és aktuális információ, jelentés és adat, megtalálható.

A National Diploma Programme-ok, vagyis a Nemzeti Diploma Programok azoknak a diákoknak nyújtanak lehetőséget, akik elköteleződtek valamilyen részterület iránt, mint például elektronika, informatika. Ezek a képzések olyan képességeket dolgoznak ki, melyek biztos háttértudást jelentenek az adott szakterületen.

A Higher National Diploma Programme-ok - Emelt Szintủ Nemzeti Diploma Programok - Felsőfokú szakképzések hazai rendszeréhez hasonlítanak legjobban. Ezek az erősen szakmai alapú kurzusok lépcsőzetesebb haladást nyújtanak a felsőoktatásba. A sikeres diákok ezen a szinten nyerhetnek felvételt vagy egyfajta garantált bejutást az egyetemre.

A legnépszerübb szakmai programok a következő vizsgákat tartalmazzák, ami azt jelenti, hogy ezek nem képzési, hanem képesítési rendszerek (vizsgaközpontok):

- $\quad$ BTEC Award (Business And Technology Education Council)

- NVQ

- City and Giuld Qualification

- Apprenticeship Programme - Gyakornoki program

Angliában 4 vizsgáztató szervezet ad ki A level minősítéseket:

(1) $\mathrm{AQA}^{25}$ - Assessment and Qualifications Alliance, kormánytól független, különböző tárgyakból tartanak vizsgákat, és adnak ki különböző szintủ tanúsítványokat GCSE, AS, A level és szakképesítéseket.

(2) $\mathrm{OCR}^{26}$ - az Egyesült Királyság másik vezető vizsgaközpontja, ugyanakkor képzéseket is nyújtanak különböző életkorú személyeknek, iskolarendszerü, részidős, munka melletti tanfolyamokkal egyetemben.

\footnotetext{
${ }^{23}$ Apprenticeships, Skills, Children and Learning Act 2009

http://www.legislation.gov.uk/ukpga/2009/22/contents

${ }^{24}$ Education Act (2011). http://www.legislation.gov.uk/ukpga/2011/21/contents

${ }^{25} \mathrm{http}: / /$ www.aqa.org.uk/

${ }^{26} \mathrm{http}$ ://www.ocr.org.uk
} 
(3) Pearson ${ }^{27}$ Edexcel, a Pearson a világ vezető oktatási cége, melynek vizsgáztatással foglalkozó része az Edexcel ${ }^{28}$. Minden szinten nyújt képzéseket és vizsgalehetőséget UK-on belül és kívül egyaránt. Specialitása az általa alapított BETEC (Business and Technology Education Council) vizsgarendszere, melyet 2009/10 akadémiai évben 80 országban 1,1 millió tanulót regisztrált.

(4) Végül, de nem utolsósorban a WJEC - Welsh Joint Education Committee, ami az Egyesült Királyság egész területén nyújt vizsgákat, végez oktatáskutatás és fejlesztést, támogatja a felnőttek tanulását, és specialitása a fiatalok müvészeti tevékenységének támogatása.

Az említett 4 szolgáltató tehát nem csak a minősítések, vizsgák területén nyújt szolgáltatásokat, de kiterjedt képzési szolgáltató is, iskolarendszerü és iskolán kívüli képzésekben 19 év alattiak és felnőttek számára egyaránt, de a szakmai továbbképzésekben is szerepet vállalnak. Müködésüket vizsgálva elmondhatjuk, hogy a továbbképzések és szakképzés különböző szegmensei a szolgáltatók szintjén nem különülnek el, legföljebb szektoriális hangsúly eltolódások vannak. A minősítési rendszer ugyan nem egységes, de nem a célcsoportok mentén tagolódik, hanem különböző kategóriák, kritériumok alapján a jelölt alkalmasságát, hozzáértését minősíti a nagyon pontosan definiált Minősítési Keretrendszer mentén. A szegmenseket a finanszírozás, és az életkori csoportok összefüggésében kezelik külön.

\section{Academic Qualifications}

A legtöbb angol iskola un. „6th Form” azután következik, hogy megszerezték a (General Certificate of Secondary Education) GCSE's vizsgát, ami egyfajta alapvizsga. Akik nem teszik le ezt a vizsgát, „6th For Colleges”-ben, lehetőséget kapnak ezt később pótolni. Ezekben általában A szinten folyik a képzés, a felsőoktatásba való bejutáshoz ez kevés, további akadémiai (elméleti) minősítést kell szerezniük. Az A-szinthez két év alatt jutnak el, amikor a GCSE's vizsga teljes 6 modulból álló A minősítés és egy 3 modulos fél AS szint. A diákok általában 2-3 A-szintet tesznek le, de az akadémiai képességeiktől és motivációiktól függően teljesíthetnek többet is. Egy független (magán) iskolában a diákok akár 5 Aszintet is teljesíthetnek, míg másol kettő is nehezen sikerül.

Az A-szint alternatívájaként számos angol középiskola Nemzetközi Érettségi Vizsgát (International Baccalaureate) is kínál, ezek száma azonban még nagyon alacsony. Az iskolarendszerrel kapcsolatos kritikák során kitérünk a vizsgarendszer szigorításával kapcsolatos szakmai véleményekre.

\footnotetext{
${ }^{27} \mathrm{http}: / / \mathrm{www} \cdot$ pearson.com/

${ }^{28} \mathrm{http}: / /$ www.edexcel.com
} 


\section{A szakképzés problémái a 2000-es évek elején}

\section{A kompetencia alapú megközelités ellentmondásai}

Az angol szakképzési rendszer problémáinak gyökerére jól rámutat Brockmann és munkatársainak tanulmánya (2008), amely a szakmai képzés angliai gyakornoki rendszerét (Apprenticeship) a céhes hagyományokra vezeti vissza, amelyben a mester a munkavégzés során vezeti be a tanoncot a szakma ismeretébe, gyakorlatába és a munkavilágába. A legalacsonyabb végzettség nem jogosít fel önálló munkavégzésre, csak irányítás mellett (NVQ1). A szakmai önállóság lépésről lépésre nő az egyes szinteken, a középfokú képzésekben zömében 1-es vagy 2-es NVQ-ra felkészítő kurzusokat kínálnak. A legújabb UTC-ékben már 2-es 3-as szakmai szintü képesítéseket találunk, melyek felkészítenek az egyetemi felvételi vizsgára, valamint az alapvizsgára, ha eddig valaki még nem szerezte meg, mivel 11 évesen jelentkezett a 6th Form képzési formára. Számuk azonban még mindig elenyésző.

A bírálók szerint ez az alacsony kimeneti szintü képzési rendszer sem innovatív tudást nem tartalmaz, hiszen csak az alapmüveletek ismétléséig jut el a tanuló, sem élethosszig tartó karriert nem tud biztosítani, továbbá a szociális és foglalkoztatási mobilitáshoz sem tud hozzájárulni. Az angol kompetencia modellt $\mathrm{M}$. Brockmann et al. (2004: 527) ,rigid, visszafelé térképező módszerként jellemzik, amelyben a szakma alapja a mühelyben van, ami érinthetetlen kiindulópontja a kompetenciák meghatározásának, megszokott munkaköri leírások vezérlik, amiből a proaktív és reflektív dolgozót kihagyják.” (id: Brockmann, 2008)

Az NVQ rendszerrel összekapcsolt szakmaiság úgy tünik azokban a gazdasági szektorokban eredményes, melyek erősen tagolt munkamegosztáson alapulnak. A munkavállalók rutin feladatokat végeznek újra meg újra, egyre ügyesebben.

Összhangban az akadémiai és a szakképzés angliai kettősségével a reformokat megelőzően a VET rendszere csak az általános képzés legalacsonyabb szintü fogalmait tartalmazta, leginkább az általános foglalkoztathatóság megteremtése volt a célja. Az úgy nevezett általános készségek oktatását - mint írás-olvasás, számolás, informatika - csak az iskola elhagyók / pályakezdők szegényes funkcionális képességeire való válaszként vezették be.

A szakképzési rendszer a munkáltató által vezérelt, minimális alapkészségeket biztosította csak olyan mértékben, amennyi a feladat elvégzéséhez éppen szükséges volt. (Jessup, 1992 id: Brockmann, 2008). Ezt a formát eredetileg azzal a céllal vezették be a 70-es években, hogy csökkentsék a magas fiatalkori munkanélküliséget. A képzési rendszer kettősségét sok kritika éri, különösen, amióta a megújuló felsőfokú szakképzések rendszerét (UTC) az egyetemekhez kapcsolták. 


\section{A Nuffield Jelentés 2008- „Gyakornoki rendszer (Apprenticeship), növekedési} kilátások. ",29

Az angol oktatáspolitikában számos felmérés, összefoglaló jelentés született az oktatás helyzetének elemzéséhez. Ez a jelentés több éves információ gyüjtés után arra keresi a választ, a 16 éves kort betöltöttek körében milyen mértékben járul hozzá a képzésben való részvétel növeléséhez a gyakornoki rendszer Angliában. Mennyiségi szempontból vizsgálja a gyakornoki rendszer alakulását. A második kérdés, a gyakornoki rendszer minőségével foglalkozik. Elismeri a jelentős javulást a szakmai végzettségek megszerzésében, de azt is vizsgálja, hogyan lehet a jövőben javítani a 14-19 évesek oktatási és képzési rendszerének általános teljesítményét.

A 16 évet betöltöttek képzésének egyik célja, hogy 2015-re a 17 évesek részvételi aránya a képzésben 90\%-ra növekedjen. A másik szándék, hogy 2013-ra a 19 évesek 85\% érje el a 2. képzettségi szintet (az egyes szint felügyelet alatt végzett segédmunkaként értelmezhető, a második szint, már betanított munka, azaz meghatározott részfeladat önálló végzésére jogosít). Ehhez járult hozzá az a jogszabály módosítás, ami a tankötelezettséget 18 éves korra emelte. Így az első elvárás feltétele könnyen megvalósul, hiszen a tanulók közel 100 százaléka 17 éves kora után is a képzésben marad. A rendszer, ami a megnövekedett hallgatói létszámot befogadja, több különböző mértékben elkülönült pályát kínál. Egyrészt a GCSE - GCE A szintjének tanulási útvonalát, melyek főként a felsőoktatásba vezetnek. Ezek a vizsgák alkalmazott, általános szakmai utak, ahol az új diplomák versenyeznek számos vizsga központ által kínált végzettséggel. A szakmunkás út, vagyis a gyakornoki rendszer 16-19 évesek és idősebbek számára áll rendelkezésre.

Az aktuális kormány (2007 - Prime Minister Gordon Brown) nagy várakozással tekintett a Gyakornoki rendszerre. Azt remélte, hogy kulcsfontosságú szerepet játszhat a kormányzat kitüzött céljainak elérésében a részvétel és a teljesítmény növelésében az oktatás területén. A jelentések azonban nem ezt igazolták (Leitch Review of Skills 2006). Brown miniszter 2007-ben a Greenwich Egyetemen tartott beszédében hangsúlyozta, hogy a gyakornoki rendszert teljes egészében át kell alakítani, a finanszírozását az egyetemekhez hasonló módon egy ellenőrző szervnek kell gyakorolni (lásd UCAS), és a finanszírozásban a magánszektornak és üzleti szférának is nagyobb szerepet szánnak.

David Lammy, a Gyakornoki rendszerért felelős miniszter szintén a munkáltatókkal való együttmüködésben látta a 2020-ra kitüzött célok megvalósításának

\footnotetext{
${ }^{29} \mathrm{http}$ ///www.nuffieldfoundation.org/sites/default/files/files/3\%20Apprenticeship $\% 20 \mathrm{I} \%$ 20Prospects\%20for\%20growth.pdf Apprenticeship I Prospets for growth 2008 Nuffield Foundation.
} 
esélyét, ami négyszázezer gyakornoki helyet jelent. A munkáltatók, a tanulók, és képzést nyújtók együttmüködése szerinte oda fog vezetni, hogy 2013-ra elegendő számú és minőségü munkavállaló lesz a fiatalok körében. Az idő úgy tünik ismét nem őt igazolta, a szakemberek és az újabb jelentések legalábbis a korábbihoz hasonló aggodalmakról számolnak be az eltelt 5-6 év után is.

A Lordok Házának Gazdasági Ügyekért Felelős Bizottsága (House of Lords Select Committee for Education) vitatja, hogy a gyakornoki rendszer lenne a legmegfelelőbb megoldás, a diploma alatti szinten. A kormányzati nyilatkozatok mind a kereslet és a kínálat között kialakult egyensúly hiányára utalnak. A keresleti oldalon több jól képzett szakmunkásra van szükség, miközben a kínálati oldalon folyamatos problémákkal találkozunk.

Más ágazatokban, melyekben nagy hagyománya van a minősítéseknek, mint például a mérnöki és építőipari szektorban, ráhangolódtak a korábbi nagy múltú képzési programokra, számos munkáltató kezdeményezi, hogy a dolgozói szerezzék meg a szükséges NVQ képesítéseket. Ezzel szemben a nemzetközi tendenciákat is az jellemzi, hogy a munkaadók visszavonulnak a képzéssel kapcsolatos kötelezettségvállalásból. Hiányában a kormányzati kezdeményezések (Train to Gain) során ösztönzőket dolgoznak ki, hogy vegyenek részt a képzésekben, támogassák a dolgozók képességeinek korszerüsítését. A munkáltatók csak az NVQ 2-3 szintjének megszerzésére motiváltak, így ezek száma nő meg erőteljesen, ami az alacsony végzettségü munkavállalók foglalkoztatási csapdáját eredményezik.

Az országos képzési jegyzék integrálja ugyan a szakmai és akadémiai képesítéseket, de ezek egyenértéküsége megkérdőjelezhető, az említett elméleti alapok hiánya miatt, föként az alacsonyabb szinteken. Grugulis (2004) beszámol a szakmai polarizációról és az alacsony képzettséget igénylő szakmák nagy arányáról az UK-ban (27\% 2001-ben), ami együtt jár az autonómia és a döntési jogkör csökkenésével. Ebben a vonatkozásban úgy tünik, a szakképzés jól tükrözi az angol munkaerőpiac struktúráját.

Egyes szakmákban nyilvánvalóan magasabb elméleti tudás szükséges a szakmai kompetenciához, ami megköveteli a felsőfokú végzettséget, ilyen például a szoftverfejlesztés és az ápolói szakma is. Ezeket a foglalkozásokat az NVQ rendszer is máshogy kezeli. A minősítési rendszer legfőbb kritikája, hogy a gyakornoki rendszer inkább a munkáltató rövid távú érdekeit szolgálja ki, és nem ad a munkavállaló kezébe széleskörü és átfogó lehetőséget. 


\section{A Wolf Jelentés ${ }^{30}$}

2010-ben a kormányváltás után prof. A. Wolf M. Gove oktatási államtitkár felkérésére jelentést készített a szakképzési kurzusokról azzal a céllal, hogy hogyan lehetne javítani a gyakorlati oktatást. Wolf elemzésében és ajánlásaiban kiemeli, hogy számos, tizenévesek számára tömegesen oktatott kurzusnak semmilyen haszna nincs a munkavállalás szempontjából. Példaként hoz egy képesítést a személyes hatékonyság növelése területén, melyben azt tanították a tizenéveseknek, hogyan igényeljék a munkanélküli juttatásokat és használják a telefont. Ezt kínálta az ASDAN jótékonysági szervezet csaknem 11000 embernek a múlt évben, ami egy GCSE minősítést ért ${ }^{31}$.

Wolf másik példájában arra utal, hogy néhány szakmunkás képzés nagyon jó az építöipar és a kézmüipar területén, a fodrász tanfolyamnak is nagyon jó a standardja, de a legtöbb kurzus semmire nem használható. Számos esetben már a tanfolyamok minősítésének elfogadását is hibásnak tartja. A finanszírozásnak a diákokat kellene követni, ahelyett, hogy az intézményeknek adják a képzésre. „Olyan rendszerünk van, amiben a szakképző intézményeket a kiadott minősítések után fizetik."- állapítja meg a szerző. Wolf javasolja, hogy vezessék be a szakmai képzésekbe az elméleti tárgyak oktatását, mint például a matematikát és angolt, ahogy Németországban teszik

Mindez egybecseng számos korábbi tanulmánnyal, melyben az angol szakmai képzések tartalmi kérdéseit feszegetik. Brockmann és munkatársai egy 2008-as tanulmányukban az angol és a francia szakképzési rendszer programjait elemzik, és rámutatnak a szakképzés angol típusának koncepcionális problémáira. Az angol rendszer a munkahelyen megszerezhető képességekre épít, kevéssé veszi tekintetbe a formális tanulási formát, célja a minősítéshez való hozzáférés kiszélesítése. A kompetencia meghatározása a minősítési rendszerben (NVQs) nem a szakképzési programhoz kötődik, hanem valójában a teljesítményértékeléséhez. Ez a megközelítés alapvetően eltér a legtöbb holisztikus modelltől, ahol a vizsga és a képzés kapcsolatban marad a tananyaggal. Ez a „tanfolyam” orientált rendszer olyan szakmai ismereteket eredményez, aminek kevéssé vagy egyáltalán nem meghatározott az elméleti tudás háttere. Az NVQs munkaalapú képzései mellett léteznek strukturált szakképzési progra-

\footnotetext{
${ }^{30}$ Review of Vocational Education - The Wolf Report 2011.

https://www.education.gov.uk/publications/standard/publicationDetail/Page1/DFE00031-2011

${ }^{31}$ Hasonló jelenségek hazánkban is megfigyelhetőek az alacsonyan kvalifikált munkaerő képzése során.

Vocational education not good enough, says Wolf report. By Angela Harrison. http://www.bbc.co.uk/news/education-12622061
} 
mok is, mint például a BTEC National Diplomas, melyekben nagyobb hangsúlyt kapnak a tudásalapú elemek.

Az utóbbi 10 évben (2011 a jelentés éve) a szakképzési minősítések száma robbanásszerüen megnőtt, többen aggódnak hogy ezek nem megfelelő minőségüek. Az egyik vezető vizsgabizottság, az Edexcel jelentése szerint a szakképzésben minősítést szerzett tanulók száma a 2003-as 66000-röl több mint 700000re emelkedett. Wolf, aki a képzés és a munkaerő piac közötti viszony szakértője, nem helyesli a gyakorlati minősítések növekedését. Arra figyelmeztet, hogy 16 és 19 évesek több mint negyedét, csaknem egyharmadát ez a képzés nem juttatja álláshoz, vagy további képzési programokhoz.

Prof. Lora Undin a Londoni Egyetem szakképzésének szóvivője abban egyet ért Wolffal, hogy túl sok fiatalember van olyan képzésekben, melyek nem elég jók (nem jók semmire?). Unwin kiemeli az 1-es és 2-ees NVQ szintet, melyek egyenértékủek a GCSEs-vel. „Túl sok ember van alacsony képzettségi szinten. Ezek a kurzusok nem elég fejlesztőek, mert a minősítések egyszerüen nem elég jók" mondta. Unwin ugyanakkor azonban óva inti a kormányt, hogy az egész minősítési rendszert összezúzza és az alapokról építse fel. A szakképzési rendszer - szerinte - az utóbbi 40 évben a politikusok játszótere volt, megszámlálhatatlan kísérlet történt megalapozott nemzeti jövőkép és egyetértés (consensus) nélkül. „Bármi legyen is a Wolf vizsgálat ajánlása, szükségünk van a nyilvános viták időszakára, mielőtt bármilyen változtatást végrehajtanánk. Ellenkező esetben megismételjük a múlt hibáit." - nyilatkozza a BBC-nek.

A Wolf vizsgálat az UTC müszaki iskolákat ösztönzi, melyek magas szintü müszaki ismereteket tanítanak a 14-19 éveszeknek. A tanfolyamokat a munkáltatókkal és az egyetemekkel dolgozzák ki és együtt müködtetik a képzéseket. Mégis a tanárok szakszervezetei aggódnak, hogy így elkülöníthetik azokat a tanulókat, akik az elméletben (academical subjects) és akik a gyakorlatban tehetségesek. Az is probléma lehet, hogy ezek az iskolák elvonják a forrásokat a már létező főiskoláktól. Szakértők szerint a Wolf jelentés fö üzenete, hogy meg kell állítani Angliában a vízvezeték szerelők és kőmüvesek szakmájának leértékelödését. A Németországihoz hasonlóan olyan szakmai kultúrát kell teremteni, amelyben megbecsülik a szakmákhoz szükséges képességeket és komoly tudást.

\section{Az angol szakképzés jelenleg zajló reformfolya- mata}

A jelenlegi konzervatív kormány Oktatási Államtitkára, Michael Gove kezdeményezésére a középiskolai érettségi rendszer átfogó reformját indította el (General 
Certificate of Secondary Education - GCSE ). Az első új rendszerü érettségik 2015-ben lesznek. Ezzel egy időben nyilvánosságra hozták a „,a Középiskolai Angol, Matematia és Természettudomány Nemzeti Kerettantervét" (National Curriculum Programmes of Study for KS4 English, Maths and Science), megváltozik a vizsgáztatás helye (minden külső vizsgáztatókhoz kerül) és az ellenőrzések módja is. A vizsgáztatás struktúráját az Ofqual szervezi, míg a tartalmi követelményeket angol, matematika, természettudományok történelem és földrajz területén a DfE (Department for Education, Oktatási Minisztérium) egyezteti. A tartalmi kérdések mellett számos szervezeti változás is történt a rendszerben.

A reform törvényi hátterét Angliában a 2009-es Oktatási Törvény (Apprenticeships, Skills, Children and Learning Act ${ }^{32}$ ), valamint a 2011-es Oktatási Törvény (Education Act $2011^{33}$ ) jelenti. A törvények szabályozzák az iskolakötelezettséget, és az iskolarendszerü képzéseket 19 éves kor alatt, valamint a továbbképzési rendszert és a felnőttképzést. A törvény alapján kinevezték a Szakképzési Alap vezérigazgatóját, megalapították a Képzési Ügynökséget „The Young People's Learning Agency" elnevezéssel, ami a 19 éves kor alatti iskolaköteles tanulók számára nyújt oktatást és képzést, valamint a tanulási nehézségekkel küzdő 19 és 25 év közöttiek diákoknak. Ezen kívül személyes szolgáltatásokat biztosítanak az oktatás területén gyermekkortól fiatalkorig. Feladata még, hogy tájékoztatást adjanak a Helyi Oktatási Hatóságok (LEAs - Local education authority) szerepéröl az oktatás képzés területén a törvényi elöírások szerint.

A reform részeként a kormány számos új hivatalt és funkciót vezetett be a szakképzés minőségfejlesztése és ellenőrzése érdekében. Ezekkel igyekeznek a forrásokat és a célokat összehangolni, a rendszert átláthatóbbá tenni. Külön hivatalt hoztak létre a képzési és intézményi akkreditációk és a vizsgáztatás koordinációjára (Office of Qualifications and Examinations Regilations - OQER / Képesítési és Vizsgaszabályozási Hivatal). A képzések és tananyagok fejlesztését a Képesítési és Tantervfejlesztési Ügynökség (The Qualifications and Curriculum Development Agency QCDA) koordinálja. A hivatali ügyintézés lebonyolítása mellett a program kiterjed a végrehajtás szintjére is, hiszen a képzésekben résztvevők számára is biztosít szolgáltatásokat, például a már említett NAS (National Apprenticeship Service) ${ }^{34}$, programjai, valamint a National Carrers Service ${ }^{35}$ hálózata, ami az egyéni képzési utak megtervezésében nyújt információs és tanácsadó szolgáltatásokat.

A reform szorosan kapcsolódik az Egyesült Királyság négy országára kiterjedő Ágazati Minősítési Reformhoz (Sector Qualification Reform), melynek kereté-

\footnotetext{
${ }^{32}$ http://www.legislation.gov.uk/ukpga/2009/22/contents/enacted

${ }^{33} \mathrm{http}: / /$ www.legislation.gov.uk/ukpga/2011/21/contents

${ }^{34} \mathrm{https}: / / \mathrm{www}$.youtube.com/user/ApprenticeshipsNAS

${ }^{35} \mathrm{https}: / / \mathrm{www}$.youtube.com/user/RightDirectionForYou
} 
ben egy cselekvési tervet dolgoztak ki az Egyesült Királyság Commission for Employment \& Skills (UKCES), a Sector Skill Councils (Ágazati Szakképzettségi Tanács) és a Standard Setting Bodies (Szabványügyi Testületek) bevonásával. Kidolgozták a Qualifications and Credit Framework (QCF) Képesítési Keretrendszert, az Ofqual a nemzetek szakképzésért felelős szervezetével (LSC, DCELLS, CCEA) biztosítja a változásokhoz szükséges infrastruktúrát ${ }^{36}$. Érezhetően támaszkodtak a piaci szereplökre a tervezés során, akik a finanszírozásban már kevésbé vállalnak felelősséget.

A képesítési keretrendszer - QCF - tartalmazza a képzések fejlesztésével és megvalósításával kapcsolatos információkat, sarokpontokat a kormány, a képző intézmények, szolgáltatók széles tábora számára (tanácsadók, tutorok is). A Skill Founding Agency (hasonlóan az egyetemek finanszírozásához) szintén a QCFen keresztül finanszírozza a 19 éves kor utáni továbbképzési és szakképzési rendszert. Tanácsokkal és javaslatokkal segíti a tanulókat az eredményesség érdekében, amit egy nyilvántartási rendszerben (Personal Learning Record Service $^{37}$ ) lehet nyomon követni, a tanulók egyedi tanulói számot (Unique Learner Numbers ${ }^{38}$ ) kapnak, így a végzettségeket személyhez kötötten tartják nyilván. Ez annál inkább fontos, hiszen a költségeket 19-25 éves kor között fele fele arányban viseli a kormány és az egyén.

A Skills Founding Agency dönti el, mit finanszíroznak a 19 év felettiek képzésében, amit a SQS cselekvési tervet kidolgozó Sector Skills Councils ajánlásai alapján választanak ki, szemben a korábbi kontroll nélkül burjánzó, sokat bírált tréningekkel. Minden SFA által indított programot (Adult Responsiveness, Train to Gain; Programmes for the Unemployed, Offender Learning and skills Service, and Apprenticeships) értékel a QCF, amihez viszonyítva eldöntik a finanszírozást, ha a program céljai megfelelőek. A képzések tartalmának támogatni kell a foglalkoztathatóság növekedését, a munkavállalók szükségleteit, valamint a munkaerőpiac hatékonyságát. 2010-ben adták ki az online listát a finanszírozás minősítési feltételiröl.

A SFA további programjai.

- $\quad$ Adult Learner Responsiveness (Felnőtt Tanulási Fogékonyság)

- $\quad$ Train to Gain (Tanulj, hogy nyerj)

- $\quad$ Programmes for the Unemployed (Programok munkanélkülieknek)

- Offender Learning and Skill Service (OLASS)

\footnotetext{
${ }^{36} \mathrm{https}$ //www.gov.uk/government/policies/improving-the-quality-of-further-educationand-skills-training

${ }^{37} \mathrm{http}: / /$ www.learningrecordsservice.org.uk/

${ }^{38} \mathrm{http}: / / \mathrm{www}$. learningrecordsservice.org.uk/products/uln/
} 
Az átmeneti időszakában biztosítja a finanszírozást a korábban indult képzések befejezéséhez.

- $\quad$ Apprenticeships (Gyakornoki Rendszer)

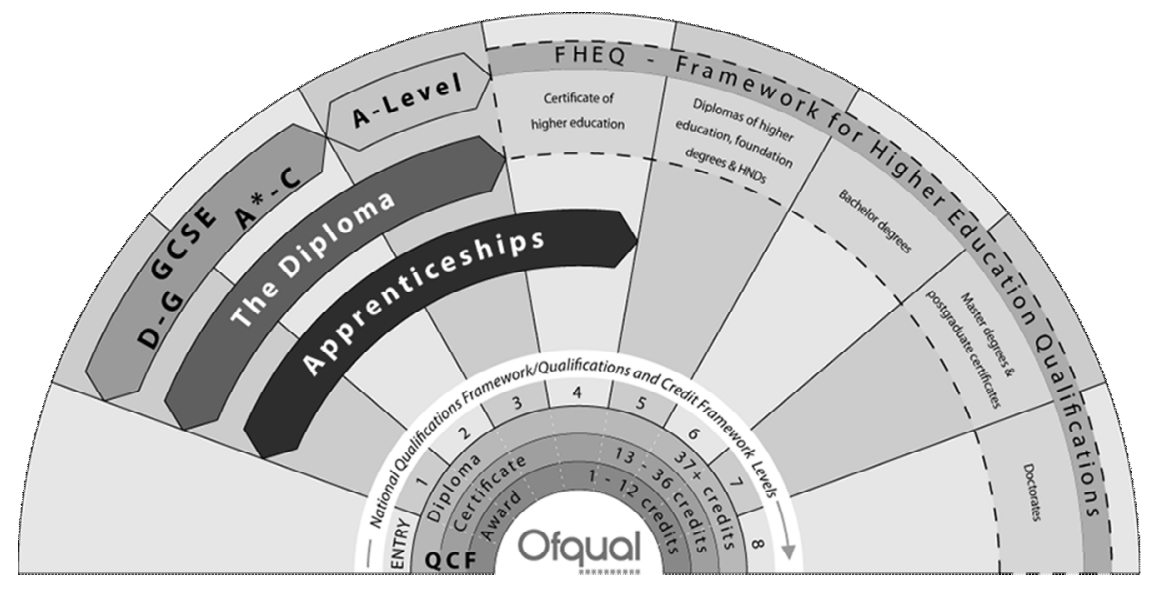

3. ábra. A képesítési rendszer egyenértéküsége Angliában.

Forrás: Ofqual (Office of Qualifications and Examinations Regulation) http://ofqual.gov.uk/help-and-advice/comparing-qualifications/

2009-ben nyilvánosságra hozták a Gyakornoki rendszer új leírását, a Specification of Apprenticeship Standard for England (SASE), amit össze kellett fésülni a minösítési rendszerrel is (QCF, NQF). Az új rendszer a különböző vizsgarendszerek minősítéseit összehangolja és átjárhatóvá teszi azt a kredit átszámítás szabályozásával, elismeri a megszerzett krediteket, ezzel különböző tanulási útvonalakat ajánl a tanulóknak. Ehhez jól használható adatbázisokra van szükség, hiszen a képző intézmények és a képzési szolgáltatók száma nagyon nagy, az általuk nyújtott tanfolyamok és képzések igen szerteágazóak. Az Oktatási Minisztérium által fenntartott állami oktatási intézményeket tartalmazza az EduBase ${ }^{39}$.

Az oktatási reformok, azon belül is a szakképzés átalakítását célzó változások ismertetéséből kitünik, mennyire átfogó strukturális változásokról van szó. A keretek, szabályozók, intézmények és müködésmódok alapvető megváltoztatása a meglévő oktatási intézmények és vizsgáztatók megőrzése mellett történikKísérletet tesznek a rendszer és a források összehangolására az Egyesült Királyság országai között és nemzeti szinten egyaránt, hogy a követelmények és az

\footnotetext{
${ }^{39} \mathrm{http}: / / w w w . e d u c a t i o n . g o v . u k /$ edubase/home.xhtml
} 
ellenőrzés szigorításával jobb minőségủ szakképzés valósuljon meg. A szabályozás és ellenőrzés növelésével az egyéni igényekhez és a változásokhoz való alkalmazkodás képessége csökken, a helyi oktatási nevelési problémákra csak lokális szinten tudnak megoldásokat találni. Kérdés, hogy a rendszer mennyi rugalmasságot enged meg.

A szabályozásban megjelenik a gazdasági szereplők bevonása, de a finanszírozásban még mindig az államé a vezető szerep. A szükségletek felmérése és a képzések fejlesztése, valamint a gyakorlati képzésben a helyi igényekre építenek, és gazdasági szereplőket is igyekeznek aktivizálni, de az oktatási rendszer szabályozásának ezt a szakaszát inkább a szakértők szük csoportjának a bevonásával történő irányítás jellemzi. Az oktatási szereplők a reformok eredményességének megítélésben megoszlanak, széles rétegük szkeptikus, az önállóságukat vesztett jól képzett tanárok kiábrándultan hagyják el a pályát.

A független külső minősítő rendszer megkívánja a képzés tartalmának, tananyagoknak a pontosabb elöírását, kidolgozását, hogy a vizsgakövetelmények egyértelmüek legyenek. Ennek érdekében mindegyik vizsgaközpont részletes tananyagot mellékel minden általa minősített képzéshez, a kapcsolódó módszertani, és tartalmi segédeszközökkel együtt. Erre szükség is van, hiszen a belső vizsgáztatás csak az angol, a nyelvtan és történelem területén maradt meg. A tananyagok online bárki számára hozzáférhetőek az ismertetett központok honlapján. Ezenkívül létezik egy központi ellenörzött tudásbázis, amit a felhasználók folyamatosan fejlesztenek.

A korábbi keretrendszert a felhasználói oldal irányította. A kompetenciák meghatározása a munkaköri feladatok elemzésén alapult, amit a teljes foglalkozási területen feltérképeztek. Az egyes funkciókat kombinálták a kompetencia elemekkel (társított teljesítmény kritériumokkal), melyeket szükségesnek ítélnek az egyes munkakörök ellátása során. Ezeket rendezték csoportokba, amit az egyes szakma NVQ-ja tartalmaz. Ugyanakkor az egyes képesítések (NVQ) kompetenciái nem kapcsolódnak tanagyagokhoz és elméleti szakmai ismeretekhez (szakismeret, anyagismeret), maga a minősítés a tanulók gyakorlati teljesítményének értékelési rendszere, amit az elöírt és elvégzett feladatokon keresztül mérnek. Így ahelyett, hogy a minősítést követően az akkreditált szakképzési programot reprezentálná, olyan kompetenciák elismerése, melyeket leginkább munkatapasztalat során szereznek, mintsem szakképzési kurzusokon. Jellemzö, hogy az elméleti tudást nem értékelik külön, bár fontosnak tartják, úgy vélik tükröződnie kell e feladat teljesítésében. A kompetenciák értékelése függ a munkahelyi teljesítménytől, így közvetve a munkáltatótól, akivel szerződéses kapcsolatban van.

Az új rendszer a fenti a gondolkodásmódot igyekszik alapvetően megváltoztatni. Elöször is minden szinten kötelezővé teszi az angol nyelv, és matematika oktatását, hangsúlyozza az idegen nyelv és a természettudományok oktatását is, 
valamint az IT és a tanulási készségek, mindennapi képességek fejlesztését, különösen a szerényebb képességü tanulók esetében. A modulokból egyéni tanulási útvonalakat választhat ki a tanuló, melyekben a tankötelezettség és a továbbtanulás szorosan összefügg.

Fontos cél, a szakképzettség növelése a Level 2 szintről (részfeladatokat önállóan elvégezni képes betanított munkás, akinek a feladata jól körülhatárolt) a Level 3-ra (önállóan dolgozó felelős szakmunkás, aki átlátja a gyártási folyamatok, az eszközök és a rendszer müködését). Fontosnak tartják az alaptanulási készségek fejlesztését és megtartását a felnőttképzés segítségével, azaz az olvasási, számolási készségek erősítését. A felnőttek vizsgálata (International Assessment of Adult Competencies - PIAAC) és a PISA felmérések azt mutatták, hogy az oktatási költségekhez és a többi tagállam (UK) eredményéhez viszonyítva Anglia gyengébben szerepelt. Sok a tanulók által félbe hagyott képzés, ami szintén pazarlás. Az akadémiai vizsgarendszer (GCSE A level) szigorításával, mintha igyekeznének az egyetemi tudományos képzések felől a szakképzésbe irányítani a fiatalokat. Az egyetemi, felsőoktatáshoz való belépéshez szükséges végzettség elérésére csak a különösen felkészült jó képességü tanulók számára válik hozzáférhetővé, még a jó és átlagos képességüeket a szakmai képesítések megszerzésére buzdítják. Hasonlóan hazánkhoz, a szakképzés hagyományos rendszere kiürült, motiválatlan, szerény képességü, hátrányos helyzetü fiatalok maradtak többségükben a rendszerben, újra teremelve az alacsony képzettséggel járó elhelyezkedési problémákat és a munkáltatók elégedetlenségét az alacsony képességü munkavállalókkal. Jellemző azonban, hogy a mégoly konzervatív oktatási államtitkár is támogatta a tankötelezettség felemelését, ugyanakkor a19 éves kor feletti szakképzés esetében is fizetni kell a tandíj 50\%-át.

\section{A továbbképzés és a szakképzés minőségének fejlesztése}

A közelmúltban a kormány megrendelésére készült, egy független szakértői jelentés „Richard felülvizsgálat $2012^{40}$, néven, amely áttekinti a Gyakornoki rendszer aktuális helyzetét és problémáit és javaslatokat fogalmaz meg a beavatkozások irányaira. Fontosnak tartja újra definiálni a szakmunkásképzéshez kapcsolódó fogalmakat, melyek negatív minősítéseket kaptak a közvéleményben. Ehhez a kutatók véleménye szerint a szakmákat, a képesítéseket is újra kell fogalmazni. A munkáltatói igények érvényesülésének is nagyobb teret kell adni. Fontos kérdésnek tartja a tanulmány, hogy hogyan lehet közelíteni a munkavállalók és a munkáltatók igényeit, és összeegyeztetni az egyéni és a szélesebb gazdasági szempontokat. Javaslata szerint meg kell vizsgálni, hogy mely elemeket kell egyszerüsíteni vagy eltávolítani a rendszerből. El kell dönteni, kinek is szól

\footnotetext{
${ }^{40}$ https://www.gov.uk/government/uploads/system/uploads/attachment_data/file/34708/ri chard-review-full.pdf
} 
a szakképzés, kinek származik a legtöbb haszna belőle (tanulók és munkáltatók egyaránt). Olyan minősítési rendszer szükségességét fogalmazza meg, amit elfogadnak és értékelnek a munkáltatók. Központi problémának tartja, hogy hogyan lehet azt megvalósítani, hogy a gyakornoki rendszer inkább új ismereteket és készségeket adjon, és ne a már meglévőket erősítse meg. Végül, de nem utolsósorban a szakképzésbe való befektetések ár-érték arányának javítását veti fel.

A beruházások és reformok ellenére az iskolaköteles korúak körében a a gyakornoki rendszer népszerüsége csökkent, a kezdeti sikerek után a program megtorpanni látszik ${ }^{41}$.

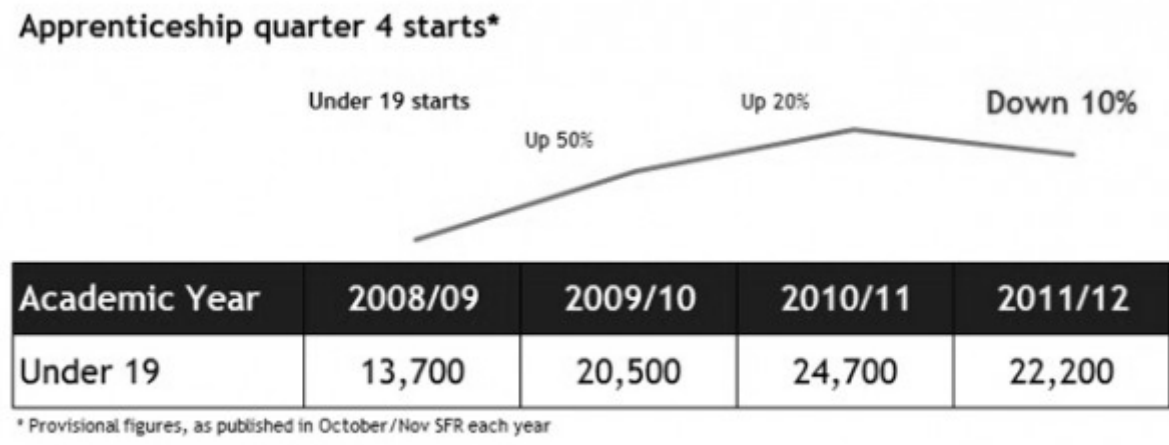

4. Táblázat. A gyakornoki rendszer.

Forrás: http://feweek.co.uk/2012/10/11/government-figures-reveal-a-ten-per-cent-fall-in16-18-apprenticeships/

A Gyakornoki rendszer (Apprenticeship) fejlesztése továbbra is prioritást élvez a kormány részéről, annak ellenére, hogy 2010 és 2011 között 10\%-kal csökkent a 16-18 évesek részvétele a rendszerben (bár a 25 feletti korosztályban nőtt). A kormányzat az oktatás fejlesztése terén töretlenül tevékenykedik, a szakértői jelentések mellett a tárgyi feltételek fejlesztésére 2013/14 és 2014/15 között 550 millió GBP tőkebefektetést fordítanak a továbbképzési intézetek felújítására (FE College $)^{42}$.

\footnotetext{
${ }^{41} \mathrm{http}: / / w w w . t e l e g r a p h . c o . u k /$ finance/jobs/9470715/British-apprenticeship-figuressuggest-drive-has-stalled.html

${ }^{42}$ FE College Capital Investment Strategy.

https://www.gov.uk/government/uploads/system/uploads/attachment_data/file/69800/121340-further-education-college-capital-investment-strategy-plan.pdf
} 


\section{Összegzés}

Az angol oktatási és szakképzési rendszer tanulmányozása során egy meglehetösen nagy múltú, nagy tekintélyü rendszerrel ismerkedhetünk meg. Hatalmas intézményrendszer, apparátus, és szakmai tapasztalat áll mögötte és a lassan 50 évre visszatekintő adósságok és a folyamatos változtatási kísérletek ellenére úgy tünik, erősen őrzi a hagyományokat, gyakran akár a modern kori kihívások ellenkező igényei ellenére is. Nem könnyü egy minősítés központú rendszert, a maga kiterjedt vizsgahálózatával és annak finanszírozási struktúrájával áthangolni, és az elmélyültebb szakmai ismeretekre épülő, az elméleti tudást és a gyakorlati készségeket ötvöző szakképzési filozófia irányába elmozdítani.

A fiatalok egy része az egyetemi diplomák irányába mozdult el - Magyarországhoz hasonlóan - ,jelentősen meg is nőtt a diplomások száma, ugyanakkor a leszakadt, az oktatási rendszerből rendkívül alacsony végzettséggel kikerülők tömegeivel is számolni kell. A munkavégzés tartalma, minősége sok ágazatban erőteljesen változik, a tudás értéke, pénzben kifejezhető differenciáló szerepe éppen ezért megerősödik. Nehéz megtalálni az egyensúlyt a túlképzés és az alul-képzés között. A társadalmi jellegü problémákra az oktatás képtelen válaszokat adni, de a helyzetet a nem megfelelő beavatkozásokkal bizony jelentősen ronthatja. Gondolunk itt a társadalmi különbségeket fokozó szelekciós mechanizmusokra, miközben az elosztás problémái már nem csak a javakhoz való hozzáférésben, hanem a munkához és a tanuláshoz, tudáshoz való hozzáférésben is megjelennek.

Önmagában ezeket a mély társadalmi problémákat egyetlen oktatási rendszer sem képes megoldani, hiába tesz akár erőn felül is erőfeszítéséket, ahogy az angol oktatási rendszer példája is mutatja. Ahogyan az oktatás nem képes önmagában kezelni a társadalmi problémákat, az oktatás politika sem tudja a rendszert csupán a szabályozók változtatásával átalakítani. Az értékek, szemléletmód, változása lassú folyamat, a szereplők aktív bevonása nélkül szinte esélytelen a kívánt eredmények elérése. Az új társadalmi és gazdasági kihívásokhoz új, talán szokatlan megoldások, ötletek megszületése szükséges, melynek kereteit a széles társadalmi vita, a konszenzus kialakítása teremti meg. A vita talán lassítja a reformfolyamatokat, valódi változások azonban csak a rendszer tagjainak belátásán, együttmüködésén és elköteleződésén alapulhatnak. Nincs az a szigorú kontroll és ellenőrzés, ami kiküszöböli a végrehajtás szintjén müködő emberek döntési szabadságát, érzelmi, akarati ellenállását, vagy éppen tehetetlenségét. Elöfordul tehát, hogy a kevesebb változás a több, és a lassabb a gyorsabb, de legalábbis hatékonyabb a szó minőségi értelmében. 


\section{Felhasznált irodalom}

1. Alexander, Robin (2012) Moral Panic, Miracle Cures and Educational Policy: what can we really learn from international comparison?, Scottish

Educational Review 44 (1), 4-21.

http://www.scotedreview.org.uk/pdf/335.pdf

2. Alexander RJ (2010) 'Post-election priorities from the Cambridge review'

The Guardian 27 April.

http://www.guardian.co.uk/education/2010/apr/27/primary-education-

cambridge-review-election

3. Alexander RJ (2009a) 'What is the primary curriculum for?' The Guardian 7 April.

http://www.guardian.co.uk/education/2009/apr/07/crib-sheet-april

4. Alexander RJ (2009b) Children, their World, their Education Final Report and Recommendations of the Cambridge Primary Review London:

Routledge.

5. Alexander RJ and Flutter J (2009a) Towards a New Primary Curriculum: a report from the Cambridge Primary Review. Part 1: Past and Present Cambridge: University of Cambridge Faculty of Education.

http://www.primaryreview.org.uk/Downloads/Curriculum_report/CPR_Cur ric_rep_Pt1_Past_Present.pdf

6. Alexander RJ and Flutter J (2009b) Towards a New Primary Curriculum: a report from the Cambridge Primary Review. Part 2: The Future Cambridge: University of Cambridge Faculty of Education.

http://www.primaryreview.org.uk/Downloads/Curriculum_report/CPR_Cur ric_rep_Pt2_Future.pdf

7. Atkins, Flint, Oldfield: Practical matters: what young people think about, vocational education in England City \& Guilds Centre for Skills Development June 2011.

http://www.skillsdevelopment.org/pdf/Practical\%20matters\%20$\% 20$ England $\% 20$ report.pdf

8. Brockmann M. Clarke L.MéhautF.Winch C. (2008) Competence-Based Vocational Education and Training(VET): the Cases of England and France in a European PerspectiveVocations and Learning (2008) 1:227-244. http://link.springer.com/article/10.1007\%2Fs 12186-008-9013-2?LI=true

9. Coffey, M. - Rhodes, C. (2002): Structure and funding of vocational education and training in the United Kingdom, Ireland, France and Germany, UTS Research Centre for Vocational Education and Training, Sydney http://www.voced.edu.au/content/ngv36114

10. Halász G (2010): Coping with complexity and instability in the VET system of the United Kingdom. http://halaszg.ofi.hu/download/UK-VET.htm 
11. Hansen K. and Vignoles A (2002) The United Kingdom Education System in Comparative Context.

http://www.cls.ioe.ac.uk/library-

media $\% 5$ Cdocuments $\% 5$ CThe $\% 20$ UK $\% 20$ Education $\% 20$ System $\% 20 \mathrm{An} \%$

20International\%20Perspective.pdf

12. Hoeckel K., Cully K., Field S., Halász G. and Kis V. (2009) OECD

Reviews of Vocational Education and Training: A Learning for Jobs

Review of England and Wales.

http://www.oecd-ilibrary.org/education/oecd-reviews-of-vocational-

education-and-training-a-learning-for-jobs-review-of-england-and-wales-

2009_9789264113763-en;jsessionid=8qgdc1q4gf4u.x-oecd-live-01

13. Lauterbach, U. and Sellin, B. (2000): Comparative Vocational Education

and Training Research in Europe: Balance and Perspectives; Cedefop/DIPF

Conference.

http://www.cedefop.europa.eu/EN/Files/BonnReaderEN.pdf

14. West J. - Steedman H.(2003) Finding Our Way: Vocational Education in England.

http://eprints.lse.ac.uk/13485/1/OP018.pdf

15. Structures of education, vocational training and adult education systems in Europe 2003.

http://eacea.ec.europa.eu/education/eurydice/documents/eurybase/structures /041_UN_EN.pdf

16. White, A. (2010) Turning the clock back to subject slavery. http://www.tes.co.uk/article.aspx?storycode $=6035006$

17. White, A. (2011) 'A properly rounded academic education'. http://www.philosophy-of-education.org/uploads/papers2011/WhiteJ.pdf

18. White, A. (2011) Gove's on the Bac foot with a white paper stuck in 1868. http://www.tes.co.uk/article.aspx?storycode $=6068033$

19. Wolf, A. (2011) Review of Vocational Education - The Wolf Report. https://www.education.gov.uk/publications/standard/publicationDetail/Page 1/DFE-00031-2011

20. Vocational education and training at higher qualification levels (2011). http://www.cedefop.europa.eu/EN/Files/5515_en.pdf

21. Vivian, D. ; Winterbotham, M. ; Shury, J. ; Davies, B. (2011): Employer Skills Survey 2011 First Findings UK Commission for Employment and Skills.

http://www.ukces.org.uk/assets/ukces/docs/publications/uk-ess-firstfindings-2011-amended-22-dec.pdf 
Internetes hivatkozások:

1. Business Plan 2012-13 of National Apprenticeship Service http://www.apprenticeships.org.uk/AboutUs/ /media/Documents/NAS2012 13BusinessPlanforstakeholders-July2012.

2. Department for Education. https://www.education.gov.uk/

3. Education in England. http://www.educationengland.org.uk

4. European Credit System for Vocational Education and Training (ECVET) for England. http://www.ecctis.co.uk/ecvet/default.aspx

5. European Centre of Develop of Vocational Training CEDEFOP. http://www.cedefop.europa.eu

6. The Education, Audiovisual and Culture Executive Agency (EACEA) Eurydice. http://eacea.ec.europa.eu/education/eurydice/

7. National Board of Education. http://www.oph.fi/english/education/vocational_upper_secondary_educatio $\mathrm{n}$ and training Finish

8. Tehnical and Vocational Training United Kingdom TVT UK. http://www.tvetuk.org/en/home

9. University Technical Colleges. http://www.utcolleges.org/

10. BBC Education and Family. http://www.bbc.co.uk/news/education

11. Ofqual a Szakképzés, a képesítések, vizsgák és értékelések szabályozója Angliában és Észak-Írországban. http://www.ofqual.gov.uk/about-us/

12. List of Additional Regulatory Documents Regulatory documents still in force from the 18th July 2011 onwards - a vizsgák kritériumokat szabályozó dokumentumok összesítése.

http://www2.ofqual.gov.uk/downloads/category/109-regulatory-documents

Zolnai Erika: pszichológus, főiskolai adjunktus

Debreceni Egyetem Egészségügyi Kar, 4400 Nyíregyháza, Sóstói u. 2-4. 


\section{Mellékletek}

1. számú Melléklet.

Az oktatási szakaszok, életkor; iskola év, Isced; KS és a különbözően tagozódó iskolatípusok összegző táblázata

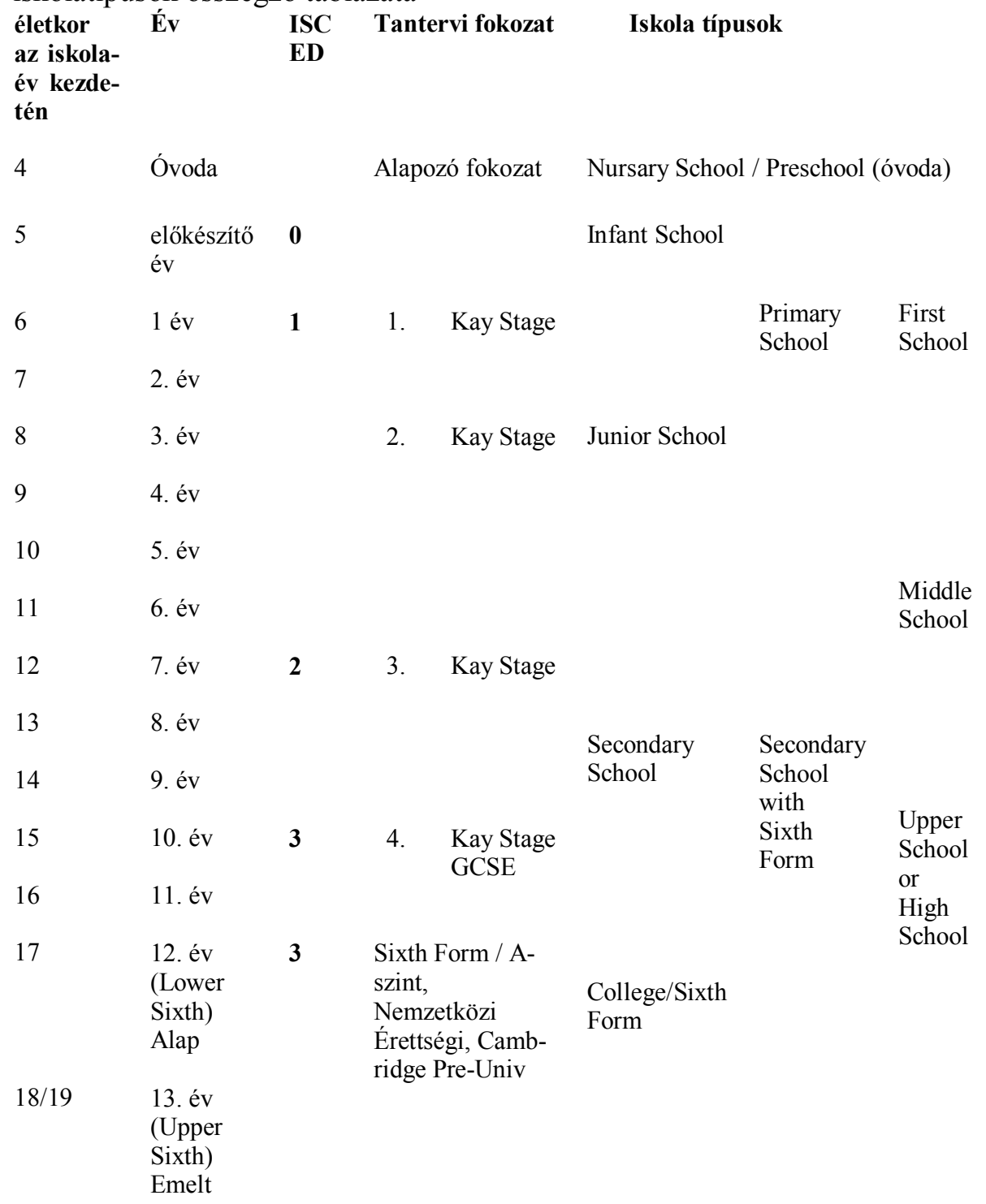

Forrás: saját szerkesztés, Eurydike és egyéb oldalak alapján 
2-es számú melléklet.

Az angol oktatás struktúrája szintek, iskolatípusok iskolaév és életkorok mentén.

\begin{tabular}{|c|c|c|c|c|c|c|}
\hline \multirow{2}{*}{\begin{tabular}{|l|}
$\begin{array}{l}\text { Phase of } \\
\text { education }\end{array}$ \\
Higher \\
and fur- \\
ther edu- \\
cation \\
\end{tabular}} & \multicolumn{2}{|l|}{$\begin{array}{l}\text { Type of institution } \\
\text { Intézmény típus }\end{array}$} & & \multicolumn{2}{|c|}{$\begin{array}{c}\text { Year/grade } \\
\text { key }\end{array}$} & \multirow{2}{*}{\begin{tabular}{|l}
$\begin{array}{c}\text { Typical } \\
\text { age }\end{array}$ \\
$18+$
\end{tabular}} \\
\hline & \begin{tabular}{|} 
Further education \\
inst.Szakképzö Föisko- \\
lák, „Harmadik Föisk., \\
Specializált Föisk., \\
Felnöttképzési közpon- \\
tok" \\
(such as further educa- \\
tion colleges, tertiary \\
col., specialist col., and \\
adult education centres)
\end{tabular} & $\begin{array}{l}\text { Higher education } \\
\text { institutions } \\
\text { (egyetemek és egyéb } \\
\text { felsőoktatási intézmé- } \\
\text { nyek) } \\
\text { universities and other } \\
\text { higher education insti- } \\
\text { tutions) }\end{array}$ & & 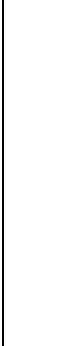 & & \\
\hline \multirow[t]{4}{*}{$\begin{array}{l}\text { Upper } \\
\text { secondary } \\
\text { education }\end{array}$} & \multicolumn{6}{|c|}{$\begin{array}{l}\text { GCE "A' Levels, GCE "AS" Level examinations and Advanced Vocational Certificates of } \\
\text { Education (AVCEs) (taken at age 17/18) provide access to further and higher education } \\
\text { and the world of work } \\
\text { GCE „,A", GCE „AS” és AVCEs vizsgák, melyek hozzáférhetövé teszik a szakképzést és } \\
\text { felsöoktatást és a munka világát. }\end{array}$} \\
\hline & $\begin{array}{l}\text { Further education } \\
\text { institutions / szak- } \\
\text { képzö int. }\end{array}$ & $\begin{array}{l}\text { School sixth forms } \\
\text { or sixth form col- } \\
\text { leges /hat oszt. Form. }\end{array}$ & & & & $17-18$ \\
\hline & & & & & & $16-17$ \\
\hline & \multicolumn{6}{|c|}{$\begin{array}{l}\text { General Certificates of Secondary Education (GCSEs), General National Vocational Quali- } \\
\text { fications (GNVQs) and GCSEs in vocational subjects (Vocational GCSEs) (usually taken at } \\
\text { age 16) provide access to post-compulsory generallacademic and vocational studies and } \\
\text { the world of work } \\
\text { GCSEs és GNVQs és Szakmai GCSEs záró, vagy képesitö vizsgák ált. } 16 \text { évesen teszik le, } \\
\text { átvezet a kötelezó képzés utáni általános, akadémiai és szakképzésbe, vagy a munka világá- } \\
\text { ba 2012-töl } 18+\text { éves korig tart a tankötelezettség }\end{array}$} \\
\hline \multirow[t]{5}{*}{\begin{tabular}{|l|} 
Lower \\
secondary \\
education
\end{tabular}} & \multicolumn{2}{|c|}{$\begin{array}{c}\text { Secondary schools / középiskolák több } \\
\text { típusa }\end{array}$} & Key stage 4 & Y11 & \multicolumn{2}{|c|}{$15-$} \\
\hline & & & & Y10 & & -15 \\
\hline & & & & Y9 & & -14 \\
\hline & & & $\begin{array}{c}\text { Key } \\
\text { stage3***** }\end{array}$ & Y8 & & $-13 * *$ \\
\hline & & & & Y7 & & $-12 * *$ \\
\hline
\end{tabular}




\begin{tabular}{|c|c|c|c|c|}
\hline \multirow[t]{6}{*}{$\begin{array}{l}\text { Primary } \\
\text { education }\end{array}$} & $\begin{array}{c}\text { Primary schools* / általános iskolák } \\
\text { több típusa }\end{array}$ & \multirow[t]{2}{*}{$\begin{array}{l}\text { Key stage } \\
2 * * * *\end{array}$} & Y6 & $10-11 * *$ \\
\hline & & & Y5 & $9-10 * *$ \\
\hline & & & Y4 & $8-9 * *$ \\
\hline & & & Y3 & $7-8$ \\
\hline & & \multirow{2}{*}{ Key stage 1} & $\mathrm{Y} 2$ & $6-7$ \\
\hline & & & Y1 & $5-6$ \\
\hline & $\begin{array}{l}\text { Reception classes }(R) \text { in } \\
\text { primary sch. }\end{array}$ & $\begin{array}{l}\text { Early Years } \\
\text { Foundation } \\
\text { stage } * * *\end{array}$ & $\mathrm{R}$ & $4-5$ \\
\hline \multirow{2}{*}{$\begin{array}{l}\text { Pre-school } \\
\text { and nursery } \\
\text { education }\end{array}$} & \multirow{2}{*}{$\begin{array}{l}\text { Pre-school settings which include pre- } \\
\text { school groups, playgroups, day nurseries, } \\
\text { nursery centres and nursery schools }\end{array}$} & & & $0-5$ \\
\hline & & & & \\
\hline
\end{tabular}


3-as számú melléklet.

A VET rendszerében résztvevő iskolatípusok és formák.

Primary Education

Secondary Education

Upper Secondary \& Postcompulsory

Higher Education
Primary Schools

Secondary Schools2

1. Community Schools

2. Foundation Schools

3. Voluntary Schools

4. Academies

5. Studio Schools

6. University Technical Colleges (jelenleg müködik:6, folyamatban:4)

Secondary Schools - Sixth Forms

1. Sixth Form College

2. Further Education College

3. Specialist College

4. Tertiary College

Higher Education Institutions

1. Further Education College

2. University

3. University College
Age 4 to 11

Age 11 to 16

Age 16 to

$18+$

Age $18+$

forrás: http://www.7eu-vet.org/uploadi/editor/1326448027England OverviewofVETSystem.pdf 
4-es számú melléklet.

A gyakornoki rendszerben tanulók számának és összetételének változásai.

Forrás: http://www.significancemagazine.org/details/webexclusive/2085083/YoureHired-Apprenticeships-since-the-1950s.html

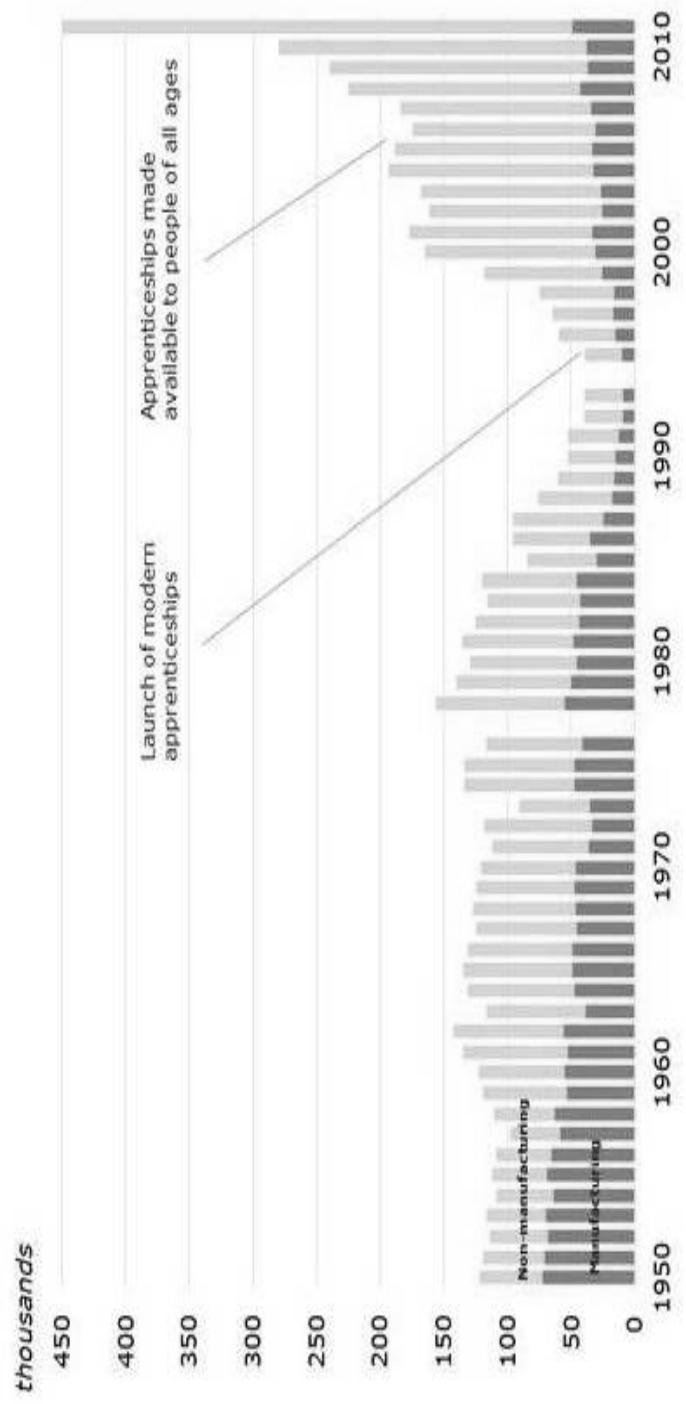


5-ös számú melléklet.

A minősítések egyenértéküsége.

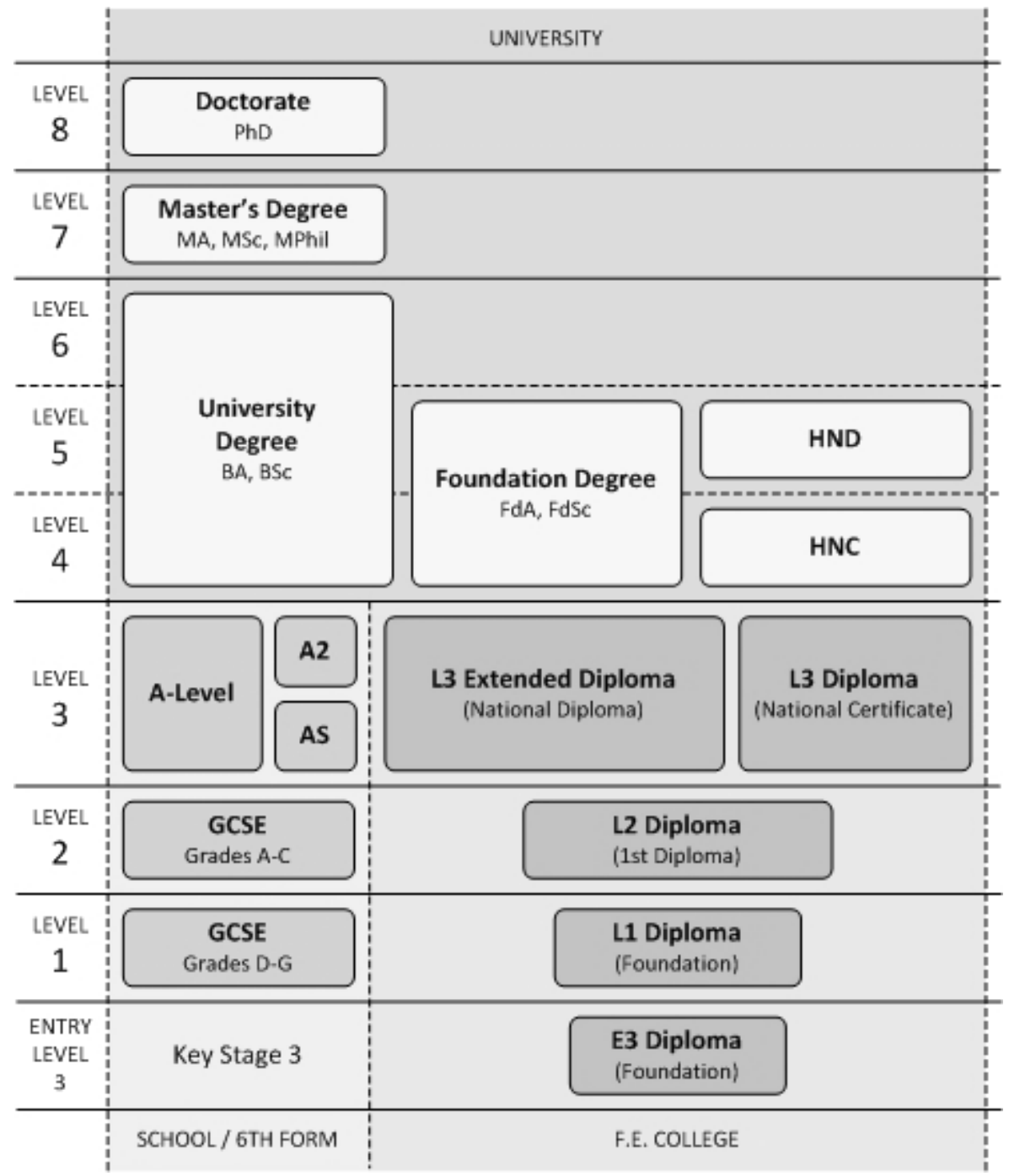

Forrás: http://www.caduk.co.uk/aboutus.html 